\title{
PROSOCIAL OCCUPATIONS, WORK AUTONOMY, AND THE ORIGINS OF THE SOCIAL CLASS PAY GAP
}

\author{
Ray Tsai Fang \\ Boise State University \\ András Tilcsik \\ University of Toronto
}

\begin{abstract}
Despite decades of research on social mobility and wage disparities, it remains a puzzle why people from lower-class families earn less than people from upper-class families even when similar in education and occupational prestige. Taking a sociocultural perspective on social class, we argue that a key contributor to the class pay gap is that people from upper-class origins tend to work in occupations with greater autonomy, whereas their lower-class counterparts tend to work in occupations that are more prosocial. We further propose that autonomous occupations pay better than prosocial occupations. Across two distinct nationally representative samples in the United States, we find that people with upper-class (versus lower-class) parents are more likely to work in autonomous occupations, but less likely to work in prosocial occupations, even when controlling for education, occupational prestige, and other potential confounds. This pattern of occupational sorting explains a substantial portion of the class pay gap. Our study extends the literatures on social class, occupational segregation, and social mobility and joins an important scholarly conversation that has until recently taken place outside the field of management.
\end{abstract}


Systematic wage disparities, or pay gaps, between different groups of people represent a major challenge for contemporary managers and organizations (Bapuji, Ertug, \& Shaw, 2020; Castilla \& Benard, 2010; Leana \& Meuris, 2015; Joshi, Son, \& Roh, 2015). Pay is both a crucial lever that employers use to manage their human resources (Shaw, 2014) and the primary source of income for working families (Piketty \& Saez, 2003). Pay gaps mean that some demographic groups (e.g., male, White, and upper-class) control more resources than do other groups (e.g., female, Black, and lower-class). Over time, pay gaps translate into societal beliefs about people's competence or esteem based on their demographic characteristics, creating "durable inequality" (Ridgeway, 2014). Because organizations are the primary sites where managers produce and sustain inequality (Castilla, 2011; Stainback, Tomaskovic-Devey, and Skaggs, 2010), management scholars are increasingly interested in understanding what contributes to pay gaps (Abraham, 2017; Bidwell, Brisco, Fernandez-Mateo, \& Sterling, 2013; Pitesa \& Pillutla, 2019). Though rarely the focus of management research, the social class pay gap - the difference in earnings between people from lower-class versus upper-class origins - is a persistent societal issue that is extensively studied in other fields (Hout, 2018; Kraus \& Tan, 2015; Solon, 1992; Weeden, Kim, Di Carlo, \& Grusky, 2007). This rich literature has uncovered several mechanisms underlying the class pay gap, particularly those that give rise to class differences in education level and occupational prestige. A common theme in this research is that because people growing up with upper-class parents have more economic, social, and cultural advantages, they are likely to attain more education and a more prestigious job, both of which produce a higher income (Lin, 1999; Rivera, 2012; Stephens, Hamedami, \& Destin, 2014). What is striking, however, is that even when controlling for education, occupational prestige, and other variables, class origin still relates to personal income (Bartik \& Hershbein, 2018; Laurison \& 
Friedman, 2016; Pitesa \& Pillutla, 2019; Rivera \& Tilcsik, 2016). In other words, people who grew up in lower-class families earn less than their peers who grew up in upper-class families, even when they are similar in education and occupational prestige. This is especially puzzling because the class pay gap appears to span the educational spectrum-from those who lack a university degree (Torche, 2011) to those graduating from Berkeley with an MBA (Pfeffer, 1977a, 1977b), suggesting the pay gap exists across low- to high-skilled occupations.

To help address this puzzle and complement existing explanations of the class pay gap, we take a sociocultural perspective on social class (Bourdieu, 1979; Lareau, 2011; Stephens \& Townsend, 2013) to develop a theory about the types of occupations in which people from different class origins work. One insight from a sociocultural perspective is that, because lowerclass children grow up in resource-scarce environments, they adopt more external, other-oriented tendencies, leading them to be more prosocial and responsive to others (Piff \& Robinson, 2017). In contrast, resource abundance during childhood promotes more internal, self-oriented tendencies, leading people from upper-class origins to desire personal freedom and influence (Belmi \& Laurin, 2016; Kohn \& Schooler, 1969). Using this perspective, we propose that people from lower-class origins tend to work in occupations that are more prosocial — those that make a positive difference in people's lives (England, Budig, \& Folbre, 2002; Grant, 2007), whereas their upper-class counterparts tend to work in occupations with more autonomy, that is, greater discretion over when, where, and how a job is to be done (Hackman \& Oldham, 1976).

This pattern of occupational sorting may help explain the class pay gap. Prosocial occupations often require advanced degrees and are considered highly prestigious (e.g., pediatricians, educators, clinical therapists; Charles, Ellis, \& England, 2015), but various factors could lead prosocial occupations to pay less than autonomous occupations (i.e., those with high 
work autonomy). Employers may assign lower salaries to prosocial occupations because society tends to devalue communal skills and responsibilities (England, 1992) and because people are willing to accept lower salaries for meaningful and prosocial work (Hu \& Hirsh, 2017). Moreover, society's tendency to celebrate independence and self-reliance (Bianchi, 2016; Markus \& Kitayama, 2010) could raise the perceived economic value of autonomous occupations (e.g., lawyers, oral surgeons, securities traders). Thus, we predicted that occupations with greater autonomy would pay higher salaries than occupations that are more prosocial even when controlling for their prestige, educational requirements, and other factors that affect salary.

Taken together, these arguments suggest a complementary explanation for the class pay gap: People from upper-class origins tend to work in autonomous occupations, which pay better than the prosocial occupations that people from lower-class origins tend to work in. We test our predictions with two distinct nationally representative U.S. samples (the General Social Survey and the National Longitudinal Survey of Youth) by matching data from the Bureau of Labor Statistics and the Occupational Information Network, two primary sources of information about occupational characteristics in the U.S. economy. The results support our hypotheses and shed light on why people from different class origins work in occupations of unequal economic rewards. This research helps resolve the puzzle of the class pay gap and contributes to broader social scientific conversations on social mobility and wage disparities.

\section{A SOCIOCULTURAL PERSPECTIVE ON THE CLASS PAY GAP}

The class pay gap is a manifestation of low intergenerational social mobility, generally defined as the relationship in social status between parents and their children (Hout, 2015). Research on social mobility spans several disciplines and provides the theoretical foundation for our analysis of the class pay gap. Therefore, we synthesize this vast literature by broadly outlining the major perspectives that describe how the class pay gap is produced and sustained. 


\section{Class Origin and Upward Mobility}

A person's social class of origin is their position of relative advantage or disadvantage vis-à-vis others in terms of their parents' educational attainment, occupational prestige, and income during childhood (Kraus, Piff, Mendoza-Denton, Rheinschmidt, \& Keltner, 2012; Martin \& Côté, 2019). ${ }^{1}$ This conceptualization of class origins follows the gradational perspective on social mobility, which emphasizes how a person's life advantages stem from their position in a socioeconomic hierarchy, and that parents pass on their socioeconomic position to their children (Weeden \& Grusky, 2012). The gradational perspective differs from the micro-class and bigclass perspectives on social mobility, both of which emphasize occupational reproduction, the idea that parents pass their line of work to their children (Jonsson, Grusky, Di Carlo, Pollak, \& Brinton, 2009). Whereas the micro-class perspective entails narrower occupational categories (e.g., lawyer, engineer, and plumber), the big-class perspective refers to broader, traditional categories (e.g., professional, manager, and laborer). We conceptualize class and social mobility in gradational terms because education and income, in addition to occupation, are important factors shaping a person's class environment (Kraus et al., 2012).

Social scientists have offered several explanations for the relationship between class origin and upward mobility. Economic explanations focus on material resources, contending that the parents of upper-class children can pay for socially valued goods and services - most important of which is a high-quality education that opens doors to prestigious occupations (Blanden, Gregg, \& Macmillan, 2007; Ingram \& Oh, 2020; Warren, Sheridan, \& Hauser, 2002). Sociological explanations emphasize the social (networks and connections) and cultural (tastes, practices, and institutions) advantages that help upper-class people navigate elite educational and

\footnotetext{
${ }^{1}$ We use upper-class and lower-class for ease of presentation and comparison when describing our theory but conceptualize class origin as a continuous rather than binary construct.
} 
organizational settings (Bourdieu, 1979; Jackson, 2009; Rivera, 2012). Psychological explanations add that upper-class children have higher aspirations and expectations than their lower-class peers, and therefore, they put more effort toward achieving more education and a more prestigious job (Belmi \& Laurin, 2016, Diemer \& Ali, 2009; Judge \& Hurst, 2007).

A common thread across these perspectives is that the higher class one's parents, the more likely that one will attain a prestigious occupation (Laurison \& Friedman, 2016). Occupational prestige - the level of respect and admiration a particular occupation holds in society—is correlated with education and income (Hauser \& Warren, 1997). The portion of occupational prestige that is unrelated to education and income stems from other occupational attributes that people respect and admire, including human capital factors related to experience, training, and unique skills (Zhou, 2005). Thus, a person's occupational prestige comprises major ingredients of their social standing in society (Piazza \& Castellucci, 2014; Zhou, 2005).

Although occupational prestige "may indeed be the best single proxy class analysis has at its disposal," it might "not fully, or even adequately, capture the effects of social origin on a person's class destination" (Laurison \& Friedman, 2016: 669). In particular, income is only moderately correlated with prestige (Nakao \& Treas, 1994). Lawyers and nurses, for instance, are comparable in prestige but lawyers enjoy more than twice the income of nurses (U.S. Bureau of Labor Statistics, 2019). Law professors are regarded as slightly more prestigious than lawyers but earn less $(\mathrm{ibid}$.). Thus, class differences in prestige - and the known factors that contribute to it (e.g., differences in education and social capital) - may only partially explain the pay gap.

\section{Occupational Sorting: The Matching of People to Occupations}

In the following sections, we describe an unexplored path by which class origin relates to occupational attainment. We propose that people from upper-class origins tend to work in occupations with more autonomy, whereas people from lower-class origins tend to work in 
occupations that are more prosocial. We then argue that these differences help explain the pay gap, above and beyond the well-substantiated influence of education and occupational prestige.

Our point of departure is a basic model of occupational sorting. Because employers and job seekers assess one another for fit (Kristof-Brown, Zimmerman, \& Johnson, 2005), the distribution of people across occupations results from a two-sided process whereby (a) job seekers are drawn to occupations in which their skills and characteristics are most valued and (b) employers hire people with the most relevant skills and characteristics. Thus, occupational sorting comprises the simultaneous influence of both supply-side factors (i.e., job seekers' preferences, characteristics, and skills) and demand-side factors (i.e., employers' needs, preferences, and biases), as well as the matching processes that bring them together (Tilcsik, Anteby, \& Knight, 2015; Bills, Di Stasio, \& Gërxhani 2017). Using this occupational-sorting lens, we explain why people from different class origins may be more likely to pursue, and be hired into, autonomous or prosocial occupations.

\section{The Sociocultural Origins of Autonomous and Prosocial Occupational Attainment}

On average, upper-class environments tend to be easier and more predictable whereas lower-class environments are more stressful and uncertain (Griskevicius et al., 2013). Children with upper-class parents typically grow up in nicer homes in safer neighborhoods with better schools and participate in more expensive activities, such as summer camps and international travel. Their lower-class counterparts tend to grow up in more disadvantaged neighborhoods and are more likely to experience economic insecurity (Lareau, 2011).

Although these material differences are profoundly consequential, a sociocultural perspective on social class suggests that class advantage also includes the sociocultural context in which people live (Bourdieu, 1979; Sørensen, 2000; Weeden \& Grusky, 2005). In other words, people from different class origins are exposed to particular sets of ideas (e.g., 
stereotypes, cultural narratives), practices (e.g., parenting styles), and institutions (e.g., workplaces, schools) that foster different understandings of how to be a person in the world (Bourdieu, 1979; Stephens \& Townsend, 2013). Thus, people from different class origins differ not only in their lifestyles and hobbies, but also in their values and moral beliefs (Martin \& Côté, 2019). From a very young age, for instance, many upper-class children are encouraged by their parents to speak their minds and experiment with creative ideas, whereas lower-class children are more often taught to follow rules and orders (Lareau, 2011). Teachers in upper-class contexts tend to respond to their students with a soft and gentle tone (Kusserow, 2004). In contrast, lowerclass children are more likely to be taught in school to recognize their place in a social hierarchy and to respect authority (Lareau, 2011; Pearlin \& Kohn, 1966). People carry these childhood experiences with them as they mature (Martin \& Côté, 2019).

Recently, researchers posit that class origins can also imprint how independent people are (an independent model of self) versus how connected to others they are (an interdependent model of self; Stephens \& Townsend, 2013). Models of self are culture-specific understandings of how people should conduct themselves (Markus \& Kitayama, 2010; Singelis, 1994). Independent models of self assume the "normatively appropriate person should influence the context, be separate from other people, and act freely based on personal motives" (Stephens, Dittmann, \& Townsend, 2017: 513). In contrast, interdependent models of self assume that "the normatively appropriate person should adjust to the conditions of the context, connect with others, and respond to the needs, preferences, and interests of others" (Stephens et al., 2017: 513). Both models of self are available across situations and places, but people tend to adopt and elaborate one more than the other (Markus \& Conner, 2013; Stevens et al., 2017). From this standpoint, 
independent and interdependent selves - fostered by childhood experiences in different class environments - are mechanisms whereby class origins may shape important life outcomes.

Independent selves and autonomy. With abundant resources, people from upper-class origins grow accustomed to pursuing their personal interests and goals with few constraints. Over time, these experiences tend to produce an independent model of self. Supporting the notion that upper-class environments foster independent selves, research demonstrates that people from upper-class origins (relative to lower-class origins) have an elevated sense of control over their situation (Kraus, Piff, \& Keltner, 2009), are more comfortable influencing people with political behavior (Belmi \& Laurin, 2016), and are more likely to act according to their own preferences (Kusserow, 2004; Stephens et al., 2014).

People with an independent model of self should be more likely to work in autonomous occupations. Relative to occupations with low levels of autonomy (e.g., auditors, nuclear technicians, and gambling dealers), those with high levels (e.g., economists, software developers, and hairdressers) afford workers more control over how they do their job (Hackman \& Oldham, 1976). Thus, people who occupy autonomous positions tend to be those who are comfortable with personal freedom and choice (Kristof-Brown et al., 2005).

From a supply-side perspective, people from upper-class origins should be more likely than their lower-class counterparts to pursue autonomous occupations because such occupations match their dispositions and norms of behavior. Research has found, for instance, that people from upper-class origins have stronger desires for power and autonomy in their daily lives (Kusserow, 2004) and in their jobs (Belmi \& Laurin, 2016; Blustein et al., 2002; Halaby, 2003). Upper-class people also tend to have stronger feelings of self-sufficiency, self-importance, and confidence (Kraus et al., 2012; Piff, 2014; Rosenberg \& Pearlin, 1978; Varnum, 2015), which 
likely allow them to feel more comfortable with pressures that come with high autonomy, such as greater personal responsibility for the consequences of one's work.

On the demand side of the labor market, employers tend to prefer naturally assertive employees when hiring for autonomous jobs (Rivera, 2016). Because upper-class people are socialized to "stand out" and "take charge" (Stephens et al., 2017), they are more likely than lower-class people to meet these expectations. For instance, upper-class undergraduate students are significantly more likely to occupy decision-making roles in student-run organizations (Soria, Hussein, \& Vue, 2014). In a study of mock interviews for a managerial position at Samsung, participants from upper-class origins received higher interview performance scores from independent judges because they projected more confidence (Belmi, Neale, Reiff, \& Ulfe, 2019). Conversely, because lower-class children are taught to follow directions and take orders if they wish to "work their way up" (Kusserow, 2004), employers may perceive lower-class job seekers as lacking fit with autonomous work. Hiring attorneys at elite law firms, for example, "expressed greater skepticism about lower-class candidates [because they] would not convey to clients that 'these are my ideas and they're worth listening to"' (Rivera \& Tilcsik, 2016: 1120).

Thus, as a result of both supply-side and demand-side factors, class origins may be positively related to people's tendency to work in autonomous occupations:

Hypothesis 1 (H1). Individuals from upper-class origins work in more autonomous occupations than do individuals from lower-class origins.

Interdependent selves and prosociality. Lower-class environments are characterized by scarce resources, high constraints, and great uncertainty (Griskevicius et al., 2013; Lareau, 2011). Navigating such an environment requires a more communal strategy_collaborating with people and making compromises (Rucker, Galinsky, \& Magee, 2018). Over time, this way of living promotes an interdependent model of self. Research finds, for instance, that people from 
lower-class (vs. upper-class) origins are more likely to take others' perspectives into consideration (Dittman, Stephens, \& Townsend, 2020), empathize with others' suffering (Stellar, Manzo, Kraus, \& Keltner, 2012), and act prosocially (Piff \& Robinson, 2017).

People with an interdependent model of self should be more likely to work in prosocial occupations, broadly defined as those that make a positive difference in people's lives (Grant, 2007; Bright, 2016). Prosocial occupations are those that entail a high degree of social interest in caring for, teaching, and helping others (e.g., counselors, educators, and nurses; England et al., 2002; Holland, 1997), or that exist in the nonprofit sector (e.g., fundraisers, community service managers, and caseworkers; Salamon \& Newhouse, 2020). A large body of research has shown that workers in such occupations tend to be prosocially motivated and have a greater understanding of others' needs and perspectives (Piatak, 2015; Word \& Park, 2009).

From a supply-side perspective, people from lower-class origins should be more likely to pursue prosocial occupations because they show a greater tendency to help others, whereas their upper-class counterparts show a greater tendency to be self-serving (Kraus et al., 2012). Piff and colleagues (2010) demonstrated that compared to upper-class people, lower-class people volunteered more personal time to help a stranger in distress and donated more tokens (redeemable for money) to an anonymous person. Another study finds that children from poorer families donate more prize tokens to an anonymous sick child than do children from richer families (Miller, Kahle, \& Hastings, 2015). In the Belmi and Laurin (2016) study, people from lower-class origins were just as likely as their upper-class peers to desire positions with power, but only if they could do so through prosocial, rather than political, means. In contrast, studies find that upper-class people are more likely to take valued items from others, lie in a negotiation, 
and cheat to win a prize (Piff, Stancato, Côté, Mendoza-Denton, \& Keltner, 2012). Thus, people from lower-class origins may be more interested in doing prosocial work.

On the demand side, employers may view lower-class people as especially well-suited for prosocial occupations, because all else equal, they should be more likely to demonstrate relevant prosocial characteristics, experiences, and credentials. One study, for instance, shows that people from lower-class origins are more likely to volunteer for a community-building project than are people from upper-class origins (Piff, Stancato, Martinez, Kraus, \& Keltner, 2012). Similarly, first-generation college students are more likely than their counterparts to attain a degree in social work, education, and healthcare (Trejo, 2016), all of which are fitting credentials for prosocial occupations (Robst, 2007). Research also suggests that, in job interviews, nonprofit hiring managers look beyond educational credentials by gauging a candidate's interpersonal orientation, social interest, and emotional intelligence (Shubert, 2014), which match the characteristics of lower-class candidates (Dittman et al., 2020; Kraus, Côté, \& Keltner, 2010).

Thus, both demand-side and supply-side arguments point to a negative relationship between class origin and prosocial occupational attainment:

Hypothesis 2 (H2). Individuals from lower-class origins work in more prosocial occupations than do individuals from upper-class origins.

\section{Occupational Characteristics and Wages}

An important focus of management research on pay gaps has been to document how organizational practices, norms, and demographic composition enable or constrain managerial bias in decision-making and reward allocation (Briscoe \& Joshi, 2017; Joshi, Liao, \& Jackson, 2006). There has also been a shift toward "bringing managers back in," that is, studying how managers shape employees' careers and earnings (Castilla, 2011). Beyond the important influence of organizational practices and managerial decisions, people's earnings also crucially 
depend on their occupations (England, 1992; Katz \& Murphy, 1992; Mouw \& Kalleberg, 2010). At the occupation level, human capital theory asserts that occupations requiring advanced skills, more difficult tasks, and greater responsibilities pay higher wages because employers must spend more to attract workers to jobs that require substantial ability and personal investment (Gerhart \& Weller, 2019; Rosen, 1986). However, because pay levels are also shaped by institutional factors that affect the perceived worth of different job responsibilities, we expect that — even among occupations of similar human capital and responsibility—prosocial occupations will pay lower wages than autonomous occupations. This prediction is based on several lines of research.

First, the people who benefit from prosocial occupations (e.g., children, seniors, and patients) often have limited resources (England et al., 2002). When those with few resources need assistance from paid workers, third parties often pay for the care (Meyer, 2000). Therefore, how much is available to pay workers in prosocial occupations largely depends on charitable donations and taxes (O’Connor, Orloff, \& Shaver, 1999). Thus, as cultural, economic, and political barriers constrain the availability of financial resources, it is more difficult to pay workers in prosocial occupations as much as workers in other occupations with similar degrees of required skill and prestige (England et al., 2002).

Second, the devaluation hypothesis (England, Allison, \& Wu, 2007) suggests that occupations requiring similar levels of human capital might lead to substantially different incomes because of a societal tendency to devalue communal job responsibilities. Communal responsibilities, which involve helping others and showing warmth, are key aspects of prosocial work (Koenig \& Eagly, 2014; Rucker et al., 2018). According to devaluation theory, these stereotypically female job responsibilities are perceived as less pay-worthy (England et al., 2007). A large literature supports devaluation theory: People perceive communal job 
responsibilities as less pay-worthy (Glick, 1991) and female-concentrated occupations generally have lower wages (Huffman \& Velasco, 1997).

Third, research demonstrates that people will accept lower salaries for meaningful work (Hu \& Hirsh, 2017). For instance, because zookeepers find their work meaningful, “employers can extract efforts from them in exchange for little material rewards" (Anteby, Chan, \& DiBenigno, 2016: 194; Bunderson \& Thompson, 2009). Studies estimate that nine out of ten employees are willing to accept somewhere between $23-32 \%$ lower salaries for personally meaningful work (Achor, Reece, Kellerman, \& Robichaux, 2018; Hu \& Hirsh, 2017). What is considered meaningful is subjective, but people tend to find prosociality meaningful because it relates to fundamental moral values of altruism and compassion (DeCelles \& Anteby, 2020; De Groot \& Steg, 2009). Notably, when people are asked to name careers that would provide a sense of personal meaning, they list prosocial vocations, such as "teacher," "nurse," and "working for a nonprofit organization," but when asked to report careers that "would fail to provide... a sense of personal meaning," they mention less prosocial but more lucrative occupations, such as “accountant," "banker," and "salesperson" (Hu \& Hirsh, 2017: 2).

In contrast, wages for autonomous occupations are not constrained by such institutional factors (England et al., 2002). Instead, research suggests that the level of autonomy in an occupation could raise its wages (Liu \& Grusky, 2013). According to one interpretation (Jensen \& Meckling, 1976; Wright, 1978), autonomous occupations may have higher wages because, given the scope of their authority and freedom, business owners must pay higher wages to ensure that workers act according to the owners' interests. Another perspective is that exercising autonomy is more challenging than following orders or standard procedures (England, Herbert, Kilbourne, Reid, \& Megdal, 1994). There is also a literature suggesting that employers tend to 
romanticize individual agency and overestimate its influence on subordinate and organizational performance (Meindl \& Ehrlich, 1987; Meindl, Ehrlich, \& Dukerich, 1985), which further suggests a cultural tendency to value and reward autonomy. Overall, prior research and theory suggest that autonomous occupations pay better than prosocial occupations:

Hypothesis 3 (H3). Autonomous occupations pay higher wages than do prosocial occupations.

Taken together, our arguments suggest that a pattern of occupational sorting underlies the class pay gap: People from different class origins work in occupations with different degrees of autonomy and prosociality, which in turn influences the financial rewards they earn at work.

Hypothesis 4 (H4). Individuals from upper-class origins have higher personal incomes than individuals from lower-class origins in part because the former work in more autonomous occupations, whereas the latter work in more prosocial occupations.

\section{METHODS}

Exploring these hypotheses required a sufficiently large and ideally nationally representative sample of people with information on their class origins, the specific occupation in which they work, and their personal income. We identified two such datasets: the General Social Survey (GSS) and the National Longitudinal Survey of Youth (NLSY). With these data, we measured the levels of autonomy and prosociality of a relatively large number of people's occupations by matching data from the Occupational Information Network $\left(\mathrm{O}^{*} \mathrm{NET}\right)$ and the Bureau of Labor Statistics (BLS), two agencies that measure characteristics of occupations. Because the GSS and the NLSY are distinct samples, each with its own methodological advantages, we present our methods and results in stages, beginning with the GSS.

\section{GENERAL SOCIAL SURVEY}

We tested our hypotheses at the individual level with GSS participants-a sample of U.S. adults who answered questions about various behavioral tendencies, attitudes, and demographics. 
The GSS currently consists of 32 independent, cross-sectional surveys fielded annually or biennially from 1972 to 2018 . The target sample size was 1,500 when administered annually and 3,000 when fielded biennially (i.e., on an annualized basis, the target sample size remained 1,500 throughout). The resulting stability in the number of observations across surveys reduces the likelihood that data collected during a certain time could have a disproportionate effect on our results. The GSS uses a strict, full-probability sampling method, relies on trained interviewers and survey methodologists, and is considered a high-quality nationally representative sample of the U.S. adult population (Ingram \& Oh, 2020; Hout, 2018). Thus, we used GSS data for all years from 1972 to 2018. Following prior social mobility research (Hout, 2018), we removed participants under the age of 25 and over the age of 69, leaving a sample size of 50,204.

The GSS records participant occupations using the 2010 U.S. Census occupational classification system, resulting in 539 occupations. Thus, we were able to create a dataset containing detailed information on people's occupations by matching the occupational characteristics data provided by O*NET and BLS to the occupations of GSS participants.

$\mathrm{O} * \mathrm{NET}$ is widely regarded as the gold standard in the study of occupational characteristics (Liu \& Grusky, 2013; Tilcsik et al., 2015). Occupational characteristics in O*NET reflect ratings by teams of trained informants, expert analysts, and job incumbents. Job incumbents' ratings come from surveying a national random sample of workers about job requirements, worker attributes, and the nature of their work. Over 230 characteristics covering work interests, activities, and skills, among other factors, have been assessed. O*NET provides occupation-level scores for each characteristic as averages across raters (roughly 40 raters per item; Handel, 2016) and does not provide individual- or job-level data. Experts at O*NET examine and organize the millions of jobs and tens of thousands of job titles in the U.S. economy 
into occupations based on similarities in the work performed rather than by jobs or job titles, which is ideal because "[jobs and job titles] are particular to a specific workplace" (Anteby et al., 2016: 188; Grant, Berg, \& Cable, 2014). O*NET is periodically updated, and to maximize the comparability of the data over time, research methods and instruments remain as consistent as possible. However, O*NET does not update every characteristic for each occupation regularly, so occupations vary in when certain characteristics were last surveyed. An overview of the data collection procedure is at https://www.onetcenter.org/dataCollection.html.

The BLS is a federal agency that provides data on labor market activity and other economic variables. Whereas O*NET provides information about the nature of an occupation's work, the BLS provides information about an occupation's demographic profile, such as the proportions of women and racial minority workers.

We collected data in 2019, and used the most updated estimates provided by O*NET and the BLS, which means that the occupational data are cross-sectional estimates of occupations in more recent years. Because key variables such as work autonomy and prosociality have been consistently defined in the scholarly literature (Hackman \& Oldham, 1976; Campbell \& Holland, 1972), and because most occupational characteristics tend to remain stable over time (Deming, 2017; Liu \& Grusky, 2013; Tilcsik et al., 2015), we matched these estimates to the occupations of GSS participants across all waves, from 1972 to $2018 .^{2}$ As a robustness check, we tested our hypotheses by matching O*NET data from 2003, and our conclusions remained robust. ${ }^{3}$

\footnotetext{
${ }^{2}$ Liu and Grusky (2013) examined the correlations between scores obtained in 1977 versus 2008 for eight occupational characteristics and found remarkable stability over time ( $r$ s ranged from .79 to .92). The weakest correlation (.79) was the level of computer skill required in an occupation, which, considering the degree of technological advancement over these years, suggests that occupational variables such as autonomy and prosocial orientation should be at least as stable. Similarly, Deming (2017) tested their hypotheses using both O*NET pre1998 data and O*NET's most updated data at the time of their data collection and found similar results.

${ }^{3}$ In our NLSY study, we have focused on the occupations of a cohort of individuals in 2017 using the updated O*NET and BLS scores we use in our GSS study and found substantively similar results.
} 
The occupational classification system used by O*NET and the BLS is based on the 2018 Standard Occupational Classification (SOC) system, which includes over 900 occupations. Of the 539 GSS occupations, 366 could be matched directly to an occupation based on the updated 2018 SOC system. Some GSS occupation titles were broader than 2018 SOC occupation titles found in the O*NET or BLS data sources. For instance, a GSS participant's occupation may be coded as "Sales and Marketing Manager," which the 2018 SOC system splits into two separate occupations: "Sales Manager" and "Marketing Manager." In these cases, we averaged the scores across the narrower O*NET and BLS occupations to merge with GSS data. We used this averaging method for 112 GSS occupations when it was clear which narrower occupations were subsumed under the broader GSS occupation.

To verify whether the narrower occupations based on the 2018 classification system were sufficiently similar to average together, we examined ICC1 and ICC2 for each occupational characteristic (e.g., proportion of female workers, work autonomy, and social interest). All tests were statistically significant at $p<.001$ : ICC1 ranged from .58 to .99 , and ICC2 ranged from .82 to .99 , indicating strong similarity between narrower occupations in their characteristics. Thus, we analyzed GSS participants for which corresponding O*NET or BLS data is available.

\section{Measures}

We derived measures of individual characteristics such as a person's geographic location or demographic background from the GSS. The BLS provided the proportion of people working for nonprofit organizations per occupation and the proportions of women and racial minorities per occupation. O*NET provided data on an occupation's task responsibilities and work context.

We are unaware of prior research measuring work autonomy and prosocial orientation with $\mathrm{O} *$ NET data. Therefore, we systematically reviewed the definition and measurement of every $\mathrm{O} *$ NET characteristic to identify variables that most clearly reflected work autonomy and 
prosocial orientation. The vast majority of $\mathrm{O} * \mathrm{NET}$ variables were clearly irrelevant to measuring work autonomy and prosocial orientation (e.g., items capturing aspects of the physical work environment or specific technical skills required for the job), so we dropped them from further consideration. We then directly compared each of the remaining items to standard definitions of work autonomy (Hackman \& Oldham, 1976) and prosociality (Grant, 2007), a process that led us to eliminate several additional items that were inconsistent with the conceptual definitions. As a result, the remaining $\mathrm{O} * \mathrm{NET}$ items were those that most directly and consistently corresponded to accepted definitions of work autonomy and prosociality. We describe our process for selecting O*NET items in more detail in the Online Appendix (p. 2). ${ }^{4}$

A description of all variables is in Table 1, where we also summarize a confirmatory factor analysis that verifies the factor structure of the multi-item $\mathrm{O}^{*} \mathrm{NET}$ characteristics.

Social class origin (GSS). Following prior research (Kraus et al., 2012; Ingram \& Oh, 2020; Piff, Kraus, \& Keltner, 2018), we measured a person's class origin by standardizing and averaging together parental education, parental occupational prestige, and parental income.

We measured parental education by averaging the number of years of education completed by a respondent's mother and father. We measured parental occupational prestige with a widely used occupational prestige scheme (Duncan, 1961). The highest value (80) is assigned to physicians and surgeons and the lowest value (16) to dining room and cafeteria attendants and bartender helpers. Mother's occupation was not a survey item in the GSS before 1994. We averaged the occupational prestige of both parents, but if a parent did not have an occupational prestige score, we used the other parent's occupational prestige score. We measured parental income with a question that asked participants to indicate their family income relative to

\footnotetext{
${ }^{4}$ The Online Appendix is available at https://osf.io/d9kzs/?view_only=1610136a4dee48a0b68a5afa14bd7222.
} 
the average American family when they were 16 years old $(1=$ far below average, $5=$ far above average). This question about income was not asked in 1996, 1998, and 2000.

Work autonomy $(\boldsymbol{O} * N E T)$. Job incumbents answered three questions on a 5-point scale: "How much decision-making freedom, without supervision, does the job offer?" $(1=n o$ freedom, 5 = a lot of freedom), "How much freedom do you have to determine the tasks, priorities, or goals of your current job?" ( 1 = no freedom, 5 = a lot of freedom $)$, and "How important is developing one's own ways of doing things, guiding oneself with little or no supervision, and depending on oneself to get things done to the performance of your current job?" $(1=$ not important, $5=$ extremely important $)$. All items were averaged together $(\alpha=.80)$. Occupations with high levels of autonomy include economists and door-to-door salespeople; those with lower levels of autonomy include nuclear engineers and fast-food cooks.

Prosocial orientation ( $O * N E T$ and $B L S)$. We measured an occupation's degree of prosociality by combining two measures: social interest and nonprofit orientation. Based on Holland's (1997) established model of vocational interests (the RIASEC), the social interest dimension captures the extent to which an occupation's work involves caring for, teaching, and helping other people. Using O*NET data for each occupation (e.g., occupation title, core tasks, and work activities), six trained $\mathrm{O} * \mathrm{NET}$ analysts indicated on a 7-point scale the extent to which an occupation satisfies this definition of social interest, and their scores were averaged together $(\kappa=.76$; see Rounds, Armstrong, Liao, Lewis, \& Rivkin, 2008, for a detailed description of the development of this measure). Occupations high on social interest include guidance counselors and registered nurses; those low on this measure include jewelers and chemical technicians.

Occupations that make a positive social impact tend to be concentrated in the nonprofit sector (Bright, 2016; Grohs, Schneiders, \& Heinze, 2015), a set of organizations that focus on 
benefiting communities and society by providing health, educational, community, welfare, and other social services (Powell \& Steinberg, 2006). Because the nonprofit sector represents a meaningful component of prosocial work that is not directly captured by $\mathrm{O}^{*} \mathrm{NET}$, we estimated each occupation's nonprofit orientation - measured as the proportion of employees working for nonprofit organizations for each occupation — with data from the BLS. Occupations that score high on nonprofit orientation include fundraisers and social workers. Occupations that score low on nonprofit orientation include air traffic controllers and mining operators. Consistent with past research (Charles et al., 2015; Themudo, 2009), and supporting the validity of this measure, nonprofit orientation was strongly correlated with the proportion of women in the occupation $(r$ $=.49, p<.001)$, and its educational level requirements $(r=.50, p<.001)$. We standardized social interest and nonprofit orientation and averaged them together $(\alpha=.84){ }^{5}$

Personal income (GSS). Participants provided their personal income, which GSS adjusted for inflation and reported in 2010 dollars. Personal income was provided by 29,332 participants. We divided personal income by 1,000 in analyses for interpretability. Our conclusions are similar when personal income is logged.

Control variables (GSS, $O * N E T$, and $B L S)$. We systematically reviewed recent empirical research on social class and social mobility (e.g., Bartik \& Hershbein, 2018; Ingram \& Oh, 2020; Judge \& Hurst, 2007; Wodtke, 2016) to identify an extensive battery of control variables that could serve as alternative explanations for the links between $(a)$ class origin and work autonomy/prosocial orientation or between $(b)$ work autonomy/prosocial orientation and personal income. Three types of controls emerged from this review, as described in Table $1 .{ }^{6}$

\footnotetext{
${ }^{5}$ Our substantive conclusions are robust to analyzing social interest and nonprofit orientation as separate variables. ${ }^{6}$ Our results also remained robust when replicating the battery of controls from any single study that directly informed our choice of control variables.
} 
First, sociodemographic controls included variables such as education, race, and immigrant status that may confound relationships between class origin, occupational outcomes, and income (Hout, 2015; Kmec, 2005). This set of controls also included the levels of work autonomy and prosociality of the parents' occupations to address an alternative explanation based on the theory of occupational reproduction, which suggests that children are more likely to work in their parents' occupations (e.g., children of doctors are more likely to become doctors; Jonsson et al., 2009). Second, geographic controls were those related to location and geographic mobility because people from upper-class origins have the resources to live in and relocate to areas with more abundant and lucrative career opportunities (Laurison \& Friedman, 2016). Third, occupational controls captured various skill requirements and other characteristics that could cause spurious associations between autonomy/prosociality and income, such as preparation level and occupational prestige.

Insert Table 1 about here

\section{Analytic Strategy}

We tested $\mathrm{H} 1$ and $\mathrm{H} 2$ by regressing work autonomy and prosocial orientation on class origin and relevant control variables. To test $\mathrm{H} 3$, we regressed personal income on work autonomy, prosocial orientation, and control variables. We tested H4 with a dual-path mediation model in which class origin predicts work autonomy and prosocial orientation, which in turn predict personal income (see Figure 1). Categorical variables (e.g., region, year) were treated as fixed effects, and all continuous variables other than personal income were standardized.

We follow prior research (Belmi et al., 2020; Ingram \& Oh, 2020) by testing hypotheses with both the class origin composite and its individual indicators. We present results with the 
class origin composite in the Results section. The detailed results with the individual facets of class origins are in the Online Appendix (p. 4, including Tables A2 and A3).

\section{Results}

Table 2 displays the correlation matrix. Table 3 presents regression results testing $\mathrm{H} 1$ and H2. Class origin positively predicted work autonomy (Model 1: $\beta=.019 S E=.005, p<.001$ ) and negatively predicted prosocial orientation (Model 2: $\beta=-.044, S E=.006, p<.001$ ). Thus, $\mathrm{H} 1$ and H2 were supported-people from upper-class origins were more likely to work in occupations with greater autonomy, and people from lower-class origins were more likely to work in occupations that are more prosocial. ${ }^{7}$ It is worth noting that class origin predicted work autonomy as strongly as parental work autonomy did (Model $1: \beta=.022, S E=.005, p<.001)$, and predicted prosocial orientation twice as strongly as parental prosocial orientation did (Model $2: \beta=.017, S E=.005, p<.01)$. Thus, the gradational perspective explained autonomous and prosocial occupational attainment as well as, or better than, the micro-class perspective. The results also suggest that class origin influences autonomous and prosocial occupational attainment one-third as much as personal education does, indicating a substantive effect from a person's childhood socioeconomic circumstances. Moreover, as we describe below, sorting into autonomous and prosocial occupations plays a key role in explaining the class pay gap.

\section{Insert Tables 2 and 3 about here}

Before testing $\mathrm{H} 3$, we first estimated the extent to which work autonomy and prosocial orientation explain the total effect of occupational segregation on the class pay gap (Table 4). In

\footnotetext{
${ }^{7}$ Our conclusions were robust to testing our hypotheses with seemingly unrelated regressions, which account for any correlation of error terms across both equations (Baltagi, 1980). In addition, when using the individual indicators of class origin, rather than its composite measure, $\mathrm{H} 1$ and $\mathrm{H} 2$ were supported for parental education and parental income, but not occupational prestige (Tables A2 and A3 in the Online Appendix).
} 
Model 1, we regressed personal income on class origin only, and found that class origin explained $3 \%$ of the variance in income, which is consistent with past research using single-year estimates of income (Torche, 2015). In Model 2, we regressed income on class origin and all occupations as fixed effects, which revealed that occupational segregation explained an additional 26 percentage points of variance in income $(29 \%-3 \%)$ and $68 \%$ of the class pay gap [(6.32 - 2.01) / 6.32]. Model 3 estimates the influence of our proposed mediators, and compared to Model 1, work autonomy and prosocial orientation together explained eight percentage points of additional variance in income and $21 \%$ of the class pay gap. Our proposed mediators explained nearly a third of the total effect of occupational segregation on the class pay gap.

Insert Table 4 about here

Table 5 shows a series of linear regressions that control for factors that contribute to the class pay gap. In the baseline model (Model 1), we controlled for basic demographics as well as factors related to occupational reproduction. In Model 2, we added controls for personal education and occupational prestige. Model 3 included work autonomy and prosocial orientation, and revealed that our mediators explain an additional portion of the class pay gap not accounted for by many existing theories of social mobility. Model 4 tests $\mathrm{H} 3$ by including the entire battery of controls. Work autonomy $(\beta=2.10, S E=.29, p<.001)$ and prosocial orientation $(\beta=-7.35$, $S E=.35, p<.001)$ remained significant predictors of personal income, supporting H3. Notably, prosocial orientation predicted income more strongly than did education or prestige.

To test H4, we conducted path analysis with all control variables as shown in Figure 1. Bootstrapped 95\% confidence intervals with 1,000 random samples indicated indirect effects via work autonomy and prosocial orientation, as both confidence intervals excluded zero. Work 
autonomy and prosocial orientation explained $23 \%$ of the class pay gap. Comparing otherwise similar people at the 10th versus the 90th percentile of class origins, Figure 1 suggests that work autonomy and prosocial orientation together explained $\$ 934$ of their pay gap (or about $\$ 1,202$ in 2021 dollars). ${ }^{8}$ Notably, the indirect effect via prosocial orientation (\$831) was larger than the indirect effect via work autonomy (\$103). Because people work an average of 44 years (U.S. Bureau of Labor Statistics), \$934 corresponds to $\$ 41,096$ (i.e., nearly $\$ 53,000$ in 2021 dollars) over a career, which — when compared to the median net worth of roughly $\$ 70,000$ for an entire U.S. household in 2010 (Vornovitsky, Gottschalck, \& Smith, 2014)—suggests that our mediators explain a non-trivial portion of the class pay gap. Thus, H4 was supported, suggesting that class origin influences income partly because people from upper-class (rather than lower-class) origins are more likely to work in autonomous occupations (which pay more) and less likely to work in prosocial occupations (which pay less).

Insert Figure 1 about here

\section{NATIONAL LONGITUDINAL SURVEY OF YOUTH}

In the previous study, we controlled for occupational characteristics such as prestige, preparation level, and cognitive abilities; thus, we compared workers in occupations of similar social status, achievement, and human capital requirements. However, there are aspects of human capital (academic performance, educational prestige, and personality traits) and social capital (networks and contacts) that we were unable to control for using the GSS. If these factors

\footnotetext{
${ }^{8} 10$ th and 90th percentiles correspond to z-scores of -1.285 and 1.285 , which is 2.57 standard deviations and significantly larger than the convention of using 1 standard deviation to calculate effect sizes. We calculated the indirect effects via work autonomy $(.019 \times 2.10 \times \$ 1,000 \times 2.57)$ and prosocial orientation $[(-.04 \times 2.57)(-7.35 \times$ $\$ 1,000)$ ] by multiplying traditional estimates by 2.57 . We converted 2010 dollars to 2021 dollars here: https://data.bls.gov/cgi-bin/cpicalc.pl
} 
also influence whether people enter occupations with different levels of work autonomy or prosociality, then they may serve as alternative explanations for our findings.

To address this possibility, we used data from the 1997 National Longitudinal Survey of Youth (NLSY97), a longitudinal study of a nationally representative cohort whose members were 12-16 years old when first surveyed in 1997 and 32-36 years old in the most recent survey in 2017 (a total of 18 survey periods). The NLSY97 was designed to document the transition from school to work and into adulthood. Participants reported their primary occupations in 2017, to which we matched data from O*NET and the BLS as we did in our GSS analyses. The NLSY97 (described at https://www.bls.gov/nls/nlsy97.htm) consists of nearly 9,000 Americans (51\% men, 49\% women) born between 1980 and 1984. Analyzed sample sizes ranged from 5,042 to 5,322 due to missing data and participant attrition.

\section{Measures}

The NLSY97 has both limitations and advantages relative to the GSS. On the one hand, because the NLSY97 does not track the occupations of parents, we could not include parental occupational prestige in our class origins measure and were unable to control for the levels of autonomy and prosociality of parental occupations. On the other hand, the NLSY97 includes a number of human and social capital factors that the GSS lacks. In particular, our NLSY97 analysis controlled for the following human capital characteristics: private school attendance (an indicator of educational prestige; Laurison \& Friedman, 2016; Stern \& Westphal, 2010), grit (a personality trait reflecting one's perseverance and passion for long-term goals; Duckworth \& Quinn, 2009), and school grades. We also controlled for whether participants contacted their "friends or relatives" during their job search, and whether they used "a school or university employment center." Details of the measures are in Table 1 and the Online Appendix (pp. 6-7).

\section{Results}


Our analytical approach mirrored that of the GSS study. Table 6 displays the results regarding H1. Class origin $(\beta=.054, S E=.014, p<.001)$, parental income $(\beta=.039, S E=.013$, $p<.01)$, and parental education $(\beta=.045, S E=.014, p<.001)$ were each positively associated with work autonomy. H1 was supported. Table 7 displays the results for testing H2. Class origin $(\beta=-.046, S E=.011, p<.001)$, parental income $(\beta=-.048, S E=.010, p<.001)$, and parental education $(\beta=-.025, S E=.011, p<.05)$, were each negatively associated with prosocial orientation. $\mathrm{H} 2$ was supported.

Insert Tables 6 and 7 about here

Table 8 shows a series of linear regressions predicting personal income. Relative to Model 1, Model 2 suggests that work autonomy and prosocial orientation together explained an additional portion of the class pay gap not accounted for by common drivers of the class pay gap, i.e., demographic variables, occupational reproduction, and personal education and occupational prestige. To test H3, we added all other control variables (Model 3). Work autonomy was positively related to income $(\beta=.95, S E=.41, p<.05)$ and prosocial orientation was negatively related to income $(\beta=-5.25, S E=.57, p<.001)$. $\mathrm{H} 3$ was again supported.

We tested H4 with the path analytic model shown in Figure 2. Bootstrapped 95\% confidence intervals with 1,000 random samples indicated indirect effects via work autonomy and prosocial orientation, as the confidence intervals excluded zero. Work autonomy and prosocial orientation explained $7 \%$ of the total class pay gap. Comparing someone at the 10 th versus the 90th percentile of class origins, Figure 2 suggests that work autonomy and prosocial orientation explained $\$ 710$ of their pay gap (about $\$ 914$ in 2021 dollars). Similar to the GSS 
study, the indirect effect via prosocial orientation (\$581) was stronger than the indirect effect via work autonomy (\$128). H4 was supported.

Overall, our key results of interest based on the NLSY data are directionally very similar to those based on the GSS. However, comparing Figures 1 and 2, the magnitudes of the estimates differ somewhat between the two data sources. These differences might stem from the differences in the sampled populations (e.g., a relatively older population in the GSS than the NLSY97) and the different sets of variables available in these two data sources (see Table 1).

Insert Table 8 and Figure 2 about here

\section{ALTERNATIVE EXPLANATIONS AND SUPPLEMENTARY ANALYSES}

Two distinct nationally representative samples support our theorized pattern of occupational sorting and demonstrate that it explains a non-trivial portion of the pay gap left unexplained by education and prestige. Given our set of control variables, our findings are likely not due to the sorting of people into occupations that differ in human capital requirements or occupational achievement. However, there remain some alternative explanations.

\section{Class Origins and the Desire to Work in High-Income Occupations}

The supply-side of our theory suggests that lower-class people have a stronger preference to do prosocial work whereas their upper-class counterparts have a stronger preference for work autonomy. An alternative view is that people from upper-class origins place more value on earning a high income and thus gravitate toward higher-paying occupations, which also tend to offer more autonomy. For the same reason, upper-class people may avoid prosocial occupations because, as we have found, prosocial work tends to suffer a wage penalty. In other words, our findings may reflect class differences in the desire to work in high-income occupations (Kasser, Ryan, Zax, \& Sameroff, 1995; Wang, Jetten, \& Steffens, 2020). 
We explore this possibility in two sets of analyses. First, we examined people's underlying work values (aspects of a job that people believe are important; Ros, Schwartz, \& Surkiss, 1999) with the "Work Orientation" module of the GSS, a survey administered to a subset of participants in 1989, 1998, 2006, and 2016. Specifically, we examined the relationships between class origin and extrinsic and prosocial work values (Online Appendix, pp. 8-9). In contrast to the above-described alternative explanation, a person's class origin was unrelated to how important they felt that "a high income" or "good promotional opportunities" are to a job. At the same time, consistent with our theory, people from lower-class origins were more likely than their upper-class peers to report that "being able to help other people" and "being useful to society" are very important aspects of a job (Table A4). This suggests that people from lowerclass families prefer to work in lower-income occupations not because they value income less than their upper-class counterparts but because they have stronger prosocial work values. ${ }^{9}$

Next, we explored whether there are class differences in people's occupational aspirations. We used the 1979 National Longitudinal Survey of Youth (NSLY79) because this survey asked younger people (ages 14-22) to identify the occupation they desire to attain at the age of 35 and coded their responses. Thus, we were able to explore directly whether there are class differences in people's occupational aspirations by matching $\mathrm{O}$ *NET characteristics to the occupational aspirations of adolescents and young adults. Consistent with our arguments, young people with upper-class parents were more likely to aspire to work in autonomous occupations, whereas their lower-class counterparts were more likely to aspire to work in prosocial occupations. Details of this analysis are in the Online Appendix (Table A5, pp. 10-11).

\footnotetext{
${ }^{9}$ As an additional robustness check, we also tested $\mathrm{H} 1$ and $\mathrm{H} 2$ (Table 3, Models 1 and 2) by controlling for personal income and found that, even among individuals with similar levels of income, people from upper-class origins were more likely to work in autonomous occupations whereas their lower-class counterparts were more likely to work in prosocial occupations.
} 


\section{Reverse Causality}

Wages shape occupational characteristics. Our theoretical model proposes that work autonomy and prosocial orientation influence occupational wages, but an alternative perspective suggests that, instead, an occupation's characteristics are a function of its wages. We explored this possibility with occupations that have experienced a substantial increase in wages over time. The financialization of the U.S. economy (the increasing size and importance of financial markets and institutions; Davis \& Kim, 2015) and the growing demand for difficult-to-automate analytical skills, such as critical thinking and problem-solving (Acemoglu \& Autor, 2011), have tremendously boosted the earnings of certain occupations. Especially since the early 2000s, earnings for finance occupations (e.g., investment bankers, financial managers, and securities traders; Lin \& Tomaskovic-Devey, 2013), and analytical occupations (e.g., medical scientists, computer scientists, and software engineers; Liu \& Grusky, 2013) have been increasing. If occupational characteristics are largely influenced by wages (rather than vice versa), then we should observe increasing work autonomy in these occupations.

Because $\mathrm{O}^{*}$ NET has measured certain occupational characteristics multiple times, we were able to explore whether levels of autonomy in finance occupations and analytic occupations have increased alongside the increase in earnings (Online Appendix, Table A6). We find that the level of work autonomy in these occupations has generally remained stable over time. Thus, we do not find evidence that higher wages lead to greater work autonomy.

Class origins shape occupational characteristics. Our theory posits a two-sided matching process involving job seeker and employer behavior. We therefore assume that work autonomy and prosocial orientation influence who wants to pursue a career in, and who is hired into, autonomous and prosocial occupations. In short, we assume occupational characteristics influence who ends up working in an occupation. An alternative view reverses the causal arrow: 
who works in an occupation might be the cause, rather than the consequence, of occupational characteristics. For example, job incumbents from upper-class backgrounds might push for more autonomy at work, and those from lower-class origins may make an occupation more prosocial.

We explored whether our findings for $\mathrm{H} 1$ and $\mathrm{H} 2$ may reflect this account of reverse causality by retesting $\mathrm{H} 1$ and $\mathrm{H} 2$ with GSS participants who were 25-29 years old (Online Appendix, p. 14). Early-career workers are unlikely to have altered their occupation's level of work autonomy or prosociality because when people enter their occupations, "an occupational community socializes its members into a particular set of shared cultural values, norms, and worldviews" (Anteby et al., 2016: 189-190). Thus, early-career workers are more likely to be shaped by the occupations they join than vice versa. If our hypotheses are supported even with this young sample, then we are likely observing an occupational sorting process because the possibility of a reverse, occupation-shaping process is less likely to be occurring. Analyzing this young sample, we still find support for H1 and H2 (see Table A7 in the Online Appendix). These findings, in addition to our above-described analyses of work values and aspirations, further suggest that our main results are not simply reflecting an occupation-shaping process.

\section{Demographic Moderators}

A theme in the literature on social class is that its effects might depend on gender and race (Neuberg \& Sng, 2013; Rivera \& Tilcsik, 2016). Accordingly, we explored whether our findings varied by gender and race using both the GSS and the NLSY97. In both datasets, the pay gap between lower- and upper-class women is smaller than the pay gap between lower- and upper-class men (see Table A8 and Figure A2), but this was not the result of gender differences in class-based occupational sorting (Table A9; Figures A3 and A4). Thus, the observed gender difference in the size of the class pay gap may simply reflect the fact that men's income distribution is more dispersed than women's (Daczo, 2012). We also found an interaction with 
race (with only the GSS data) such that the negative relationship between class origin and prosocial orientation is weaker for Black people compared to White people, suggesting that upper-class Black people are more likely to work in prosocial occupations than upper-class White people (Table A9 and Figure A5). No other notable interactions with region, location type, or generational cohort emerged in our analyses.

\section{DISCUSSION}

Despite management scholars advancing the conversation on demographic wage disparities in recent years, they have been relatively silent on the topic of the class pay gap. As a pressing societal challenge, however, the class pay gap has long attracted the attention of researchers in other disciplines. Yet, the influence of a person's class of origin on their income still presents unresolved issues, namely, that people from lower-class families earn less than their upper-class counterparts even when they are similar in their education and occupational prestige.

In this study, we fuse $(a)$ the sociocultural perspective on social class (Stephens \& Townsend, 2013) with (b) insights from research on occupational wage inequality (England et al., 2002; Hu \& Hirsh, 2017) to develop and test a theory of class reproduction: People from upper-class origins have higher salaries than people from lower-class origins because the former work in more autonomous occupations whereas the latter work in more prosocial occupations. Across two distinct nationally representative samples, we have found support for this theory.

Work autonomy and prosocial orientation explained a substantial portion of the remaining pay gap after controlling for education and occupational prestige. The effects of our mediators, while relatively modest when compared to the well-established effects of education and occupational prestige, are substantive not only because they contribute to the class pay gap, but also because pay gaps cumulate over time and across generations. When taking an 
intergenerational view, occupational sorting in terms of work autonomy and prosociality may create significant disparities in wealth and status between families.

\section{Implications for Research on Social Class, Occupational Segregation, and Wage Inequality}

This study advances research on social class by demonstrating that class origins can influence autonomous and prosocial occupational attainment. Researchers often study class differences in autonomous and prosocial behaviors in nonwork settings (e.g., donating tokens to other participants as a signal of prosocial behavior, selecting a unique pen as autonomous behavior). These studies are important contributions to the literature, but they limit what we can infer about how such class differences manifest in labor markets and organizations. In contrast, our research examines a relatively unexplored pattern of class-based occupational sorting.

Our study also contributes to the literature on occupational segregation. Organizational scholars have been fascinated with how occupational processes "aggregate to form a landscape of inequality" by determining who can become a member of a particular occupation (Anteby et al., 2016: 195). Recent evidence shows that decision-makers in some fields, such as management consulting, law, banking, and academia, may discriminate against lower-class candidates for their lack of upper-class cultural capital (Anteby, 2013; Rivera, 2012; Rivera \& Tilcsik, 2016). This research, however, focuses on demand-side factors and examines how class inequality is reproduced via unequal access to a narrow set of prestigious occupations. Our study, in contrast, examines nearly all occupations in the U.S. economy and sheds light on how and why class background influences career outcomes above and beyond its effects on occupational prestige.

Finally, our study extends research on wage inequality by demonstrating its consequences for social mobility. Consistent with devaluation theory (England, 1992) and research on the psychology of meaningful work (Hu \& Hirsh, 2017), we find that prosocial occupations pay 
lower salaries than we would expect based on other critical job characteristics, such as skill demands, required educational credentials, and even prestige. Our results suggest that the cultural devaluation of female-typed job responsibilities and people's tendency to sacrifice salary for meaningful work (England et al., 2002) have broader consequences than previously assumed.

\section{Addressing Occupational Segregation and the Class Pay Gap}

Class-based occupational segregation - the systematic matching of people to occupations based on their class origins - contributes to the class pay gap and suggests that organizations might be using suboptimal hiring and compensation practices (Rivera, 2012; Rivera \& Tilcsik, 2016). To limit class-based occupational segregation, organizations can prioritize task performance as a selection criterion. Managers may conduct a job analysis to acquire a thorough understanding of the essential functions of a job, and use that information to guide their hiring decisions (Levine, Ash, Hall, \& Sistrunk, 1983). Structured interview questions and work samples derived from job analyses, for example, weaken the effects of biases on hiring decisions and are reliable predictors of task performance (Hunter \& Hunter, 1984). If culture fit is critical to the organization, then managers should transparently define what exactly it means before applying it as an evaluative criterion. Defining culture fit deters managers from hiring people with common social experiences and interests, and encourages them to hire those with values critical to the organization's strategy (Williams, Multhaup, \& Mihaylo, 2018).

Managers can also prevent occupational segregation from exacerbating the class pay gap by avoiding overpaying for work autonomy and underpaying for prosociality. For instance, compensation managers might conduct a job evaluation, a procedure for measuring the relative worth of the organization's jobs by identifying compensable factors - job characteristics that the organization values and chooses to pay for (Noe, Hollenbeck, Gerhart, \& Wright, 2000). Jobs are rated on each compensable factor, with expert raters assigning more points to factors when they 
are considered more crucial to the organization and when the job requires a high level of that factor. Adding accountability and transparency in pay decisions may also help align compensable factors with the organization's mission and strategy. Whereas accountability facilitates more careful and analytical compensation decisions, transparency makes unjustified pay disparities more noticeable and easier to correct (Castilla, 2015); thus, both may help prevent the overvaluation of autonomous jobs and the under-compensation of prosocial work.

Though such solutions are readily available in theory, managerial rigidity often prevents organizations from improving their hiring and compensation practices (Staw, Sandelands, \& Dutton, 1981). Moreover, it may well be out of scope for any single organization to solve the challenge of class-based occupational segregation on its own, especially when broader cultural and historical factors constrain the perceived economic value of autonomy and prosociality. Thus, larger institutional changes are likely needed to curtail the adverse effects of occupational segregation and the class pay gap.

Business schools, for instance, may help organizations improve their practices on a broader scale. Research shows that business schools are primary venues for the socialization and education of corporate executives, HR professionals, and other key decision-makers; changes in the content of graduate business education can thus have significant long-term consequences on managerial practices (Jung \& Shin, 2019). Educators may consider raising student awareness of class-based occupational sorting, suggest work practices that may alleviate its adverse effects, and encourage managers to implement such practices in their organizations.

There may also be a need to rethink the declining role of unions in business and society. Although critics raise understandable concerns about the downsides of unions, there is substantial evidence that unions are effective at reducing wage inequality between certain classes 
of workers, including those with autonomy versus those that are more prosocial, such as educational administrators versus teachers, or hospital directors versus nurses (Card, 1996; Cobb, 2016; Hirsch \& Schumacher, 1998; Ravitch, 2007). Unions can elevate wages for non-union workers in the same occupation as well because union and non-union workers share a common labor market (Kahn, 1978). Thus, labor unions and other collective voice systems, could help address pay disparities between autonomous and prosocial occupations and thus may play a role in guiding organizations toward addressing the class pay gap.

\section{Future Research}

Our study has several limitations that future research might address. One limitation is the possibility of omitted variable bias. For example, work autonomy and prosocial orientation may be correlated with some unmeasured occupational characteristics that contribute to the class pay gap. Similarly, we did not directly control for a person's cognitive ability, which some have suggested contributes to income inequality (Warren et al., 2002). Education, school grades, grit, and the levels of preparation, prestige, and cognitive skill of occupations (all of which we control for in some of our analyses) should overlap with other potentially relevant occupational characteristics and cognitive ability, but future research may establish the extent to which these or other variables not included in this study help explain the class pay gap.

Class-based occupational segregation might also mean that certain aspects of occupations could be influenced by the proportion of upper- or lower-class people working in them. Although we did not find evidence of such an influence in our supplementary analyses, our approach did not entirely rule out the possibility, especially if the occupation-shaping effects are subtle or if they emerge in occupations we did not analyze. Because people bring their characteristics and tendencies with them to work, future research could explore the possibility that the proportion of upper- or lower-class people in a particular occupation shapes the nature of the occupation itself. 
Finally, an intriguing avenue for future research would be to explore intra-occupational variation. For example, although social work as a profession has a prosocial mission and reputation, social workers in some institutional contexts function less as care providers and more as "soft cops" of the state whose work facilitates the social control of marginalized people (Ferguson, 2008). Our data- best suited to uncovering broad occupational patterns — did not provide enough granularity to explore such variation. Because it is likely the promise of the prosocial impact of an occupation as a whole that attracts people from lower-class origins, this type of variation would not affect our main conclusions. Yet, the possible divergence between the promise and realities of a job and how it might affect job seekers from different class origins represent important areas for future research. 


\section{REFERENCES}

Abraham, M. 2017. Pay formalization revisited: Considering the effects of manager gender and discretion on closing the gender wage gap. Academy of Management Journal, 60(1): 2954.

Acemoglu, D., \& Autor, D. 2011. Skills, tasks and technologies: Implications for employment and earnings. In Handbook of labor economics (Vol. 4, pp. 1043-1171). Elsevier.

Achor, S., Kellerman, G. R., Reece, A., \& Robichaux, A. 2018. America’s loneliest workers, according to research. Harvard Business Review, available at: https://hbr. org/2018/03/americas-loneliest-workers-according-toresearch.

Anteby, M. 2013. Manufacturing morals: The values of silence in business school education. Chicago, IL: University of Chicago Press.

Anteby, M., Chan, C. K., \& DiBenigno, J. 2016. Three lenses on occupations and professions in organizations: Becoming, doing, and relating. Academy of Management Annals, 10(1): 183-244.

Baltagi, B. H. 1980. On seemingly unrelated regressions with error components. Econometrica: Journal of the Econometric Society, 48(6): 1547-1551.

Bapuji, H., Ertug, G. \& Shaw, J.D. 2020. Organizations and societal economic inequality: A review and way forward. Academy of Management Annals, 14(1): 60-91.

Bartik, T. J., \& Hershbein, B. J. 2018. Degrees of poverty: The relationship between family income background and the returns to education. Upjohn Institute. Working Paper 18284. Kalamazoo, MI: W.E. Upjohn Institute for Employment Research.

Belmi, P., \& Laurin, K. 2016. Who wants to get to the top? Class and lay theories about power. Journal of Personality and Social Psychology, 111(4): 505-521.

Belmi, P., Neale, M. A., Reiff, D., \& Ulfe, R. 2019. The social advantage of miscalibrated individuals: The relationship between social class and overconfidence and its implications for class-based inequality. Journal of Personality and Social Psychology, 118(2): 254-282.

Bianchi, E. C. 2016. American individualism rises and falls with the economy: Cross-temporal evidence that individualism declines when the economy falters. Journal of Personality and Social Psychology, 111(4): 567-584.

Bidwell, M., Briscoe, F., Fernandez-Mateo, I., \& Sterling, A. 2013. The employment relationship and inequality: How and why changes in employment practices are reshaping rewards in organizations. Academy of Management Annals, 7(1): 61-121. 
Bills, D.B., Di Stasio, V. and Gërxhani, K., 2017. The demand side of hiring: Employers in the labor market. Annual Review of Sociology, 43: 291-310.

Blanden, J., Gregg, P., \& Macmillan, L. 2007. Accounting for intergenerational income persistence: noncognitive skills, ability and education. The Economic Journal, 117(519): C43-C60.

Blustein, D. L., Chaves, A. P., Diemer, M. A., Gallagher, L. A., Marshall, K. G., Sirin, S., \& Bhati, K. S. (2002). Voices of the forgotten half: The role of social class in the school-towork transition. Journal of Counseling Psychology, 49(3): 311-323.

Bourdieu, P. 1979. Symbolic power. Critique of Anthropology, 4: 77-85.

Briscoe, F., \& Joshi, A. 2017. Bringing the boss's politics in: Supervisor political ideology and the gender gap in earnings. Academy of Management Journal, 60(4): 1415-1441.

Bright, L. 2016. Is public service motivation a better explanation of nonprofit career preferences than government career preferences?. Public Personnel Management, 45(4): 405-424.

Bunderson, J. S., \& Thompson, J. A. 2009. The call of the wild: Zookeepers, callings, and the double-edged sword of deeply meaningful work. Administrative Science Quarterly, 54(1): 32-57.

Campbell, D. P., \& Holland, J. L. 1972. A merger in vocational interest research: Applying Holland's theory to Strong's data. Journal of Vocational behavior, 2(4): 353-376.

Card, D. 1996. The effect of unions on the structure of wages: A longitudinal analysis. Econometrica: Journal of the Econometric Society, 64(4): 957-979.

Castilla, E. J. 2011. Bringing managers back in: Managerial influences on workplace inequality. American Sociological Review, 76(5): 667-694.

Castilla, E. J. 2015. Accounting for the gap: A firm study manipulating organizational accountability and transparency in pay decisions. Organization Science, 26(2): 311-333.

Castilla, E. J., \& Benard, S. 2010. The paradox of meritocracy in organizations. Administrative Science Quarterly, 55(4): 543-676.

Charles, M., Ellis, C., \& England, P. 2015. Is there a caring class? Intergenerational transmission of care work. Sociological Science, 2: 527-543.

Clearfield, C. and Tilcsik, A. 2018. Meltdown: Why our systems fail and what we can do about it. New York: Penguin.

Daczo, Z. 2012. Wage inequality and the gender wage gap: Are American women swimming upstream?. Unpublished doctoral dissertation, University of Maryland. 
Davis, G.F. 2017. How institutions create income inequality. In R. Greenwood, C. Oliver, T.B. Lawrence \& R.E. Meyer (Eds.) The SAGE handbook of organizational institutionalism: 689-704. Thousand Oaks, CA: Sage.

Davis, G. F., \& Kim, S. 2015. Financialization of the economy. Annual Review of Sociology, 41: 203-221.

DeCelles, K. A., \& Anteby, M. 2020. Compassion in the clink: When and how human services workers overcome barriers to care. Organization Science, 3: 1-24.

De Groot, J. I., \& Steg, L. 2009. Morality and prosocial behavior: The role of awareness, responsibility, and norms in the norm activation model. The Journal of Social Psychology, 149(4): 425-449.

Deming, D. J. 2017. The growing importance of social skills in the labor market. The Quarterly Journal of Economics, 132(4): 1593-1640.

Diemer, M. A., \& Rasheed Ali, S. 2009. Integrating social class into vocational psychology: Theory and practice implications. Journal of Career Assessment, 17(3): 247-265.

Dittmann, A. G., Stephens, N. M., \& Townsend, S. S. 2020. Achievement is not class-neutral: Working together benefits people from working-class contexts. Journal of Personality and Social Psychology, 119(3): 517-539.

Duckworth, A. L., \& Quinn, P. D. 2009. Development and validation of the Short Grit Scale (GRIT-S). Journal of Personality Assessment, 91(2): 166-174.

Duncan, O. D. 1961. A socioeconomic index for all occupations. In Occupations and social status (Albert J. Reiss, Jr., Ed.), pp.109-161, Free Press, Glencoe, IL.

England, P. 1992. Comparable worth: Theories and evidence. Hawthorne, NY: Transaction Publishers.

England, P., Allison, P., \& Wu, Y. 2007. Does bad pay cause occupations to feminize, does feminization reduce pay, and how can we tell with longitudinal data?. Social Science Research, 36(3): 1237-1256.

England, P., Budig, M., \& Folbre, N. 2002. Wages of virtue: The relative pay of care work. Social Problems, 49(4): 455-473.

England, P., Herbert, M. S., Kilbourne, B. S., Reid, L. L., \& Megdal, L. M. 1994. The gendered valuation of occupations and skills: Earnings in 1980 census occupations. Social Forces, 73(1): $65-100$.

Ferguson, I. 2008. Reclaiming social work. London: SAGE. 
Gerhart, B., \& Weller, I. 2019. Compensation. In A. Wilkinson, N. Bacon, D. Lepak, \& S. Snell (Eds.), The handbook of human resource management (pp. 210-237). London: Sage, 2nd Edition.

Glick, P. 1991. Trait-based and sex-based discrimination in occupational prestige, occupational salary, and hiring. Sex Roles, 25(6): 351-378.

Grant, A. M. 2007. Relational job design and the motivation to make a prosocial difference. Academy of Management Review, 32(2): 393-417.

Grant, A. M., Berg, J. M., \& Cable, D. M. 2014. Job titles as identity badges: How self-reflective titles can reduce emotional exhaustion. Academy of Management Journal, 57(4): 12011225 .

Griskevicius, V., Ackerman, J. M., Cantú, S. M., Delton, A. W., Robertson, T. E., Simpson, J. A., ... \& Tybur, J. M. 2013. When the economy falters, do people spend or save? Responses to resource scarcity depend on childhood environments. Psychological Science, 24(2): 197-205.

Grohs, S., Schneiders, K., \& Heinze, R. G. 2015. Social entrepreneurship versus intrapreneurship in the German social welfare state: A study of old-age care and youth welfare services. Nonprofit and Voluntary Sector Quarterly, 44(1): 163-180.

Hackman, J. R., \& Oldham, G. 1976. Motivation through the design of work: Test of a theory. Organizational Behavior and Human Performance, 16(2): 250-279.

Halaby, C. N. 2003. Where job values come from: Family and schooling background, cognitive ability, and gender. American Sociological Review, 68(2): 251-278.

Handel, M. J. 2016. The O* NET content model: strengths and limitations. Journal for Labour Market Research, 49(2): 157-176.

Hauser, R. M., \& Warren, J. R. 1997. Socioeconomic indexes for occupations: A review, update, and critique. Sociological Methodology, 27(1): 177-298.

Hirsch, B. T., \& Schumacher, E. J. 1998. Unions, wages, and skills. Journal of Human Resources, 33(1): 201-219.

Holland, J. L. 1997. Making vocational choices: A theory of vocational personalities and work environments. Englewood Cliffs, NJ: Prentice-Hall.

Hout, M. 2015. A summary of what we know about social mobility. The ANNALS of the American Academy of Political and Social Science, 657(1): 27-36.

Hout, M. 2018. Americans' occupational status reflects the status of both of their parents. Proceedings of the National Academy of Sciences, 115(38): 9527-9532. 
Hu, J., \& Hirsh, J. B. 2017. Accepting lower salaries for meaningful work. Frontiers in Psychology, 8: 1649-1658.

Huffman, M. L., \& Velasco, S. C. 1997. When more is less: Sex composition, organizations, and earnings in US firms. Work and Occupations, 24(2): 214-244.

Hunter, J. E., \& Hunter, R. F. 1984. Validity and utility of alternative predictors of job performance. Psychological Bulletin, 96(1): 72-98.

Ingram, P., \& Oh, J. J. in press. Mapping the class ceiling: The social class disadvantage for attaining management positions. Academy of Management Discoveries, Retrieved at https://journals.aom.org/doi/10.5465/amd.2020.0030

Jackson, M. 2009. Disadvantaged through discrimination? The role of employers in social stratification 1. The British Journal of Sociology, 60(4): 669-692.

Jensen, M. C., \& Meckling, W. H. 1976. Theory of the firm: Managerial behavior, agency costs and ownership structure. Journal of Financial Economics, 3(4): 305-360.

Jonsson, J. O., Grusky, D. B., Di Carlo, M., Pollak, R., \& Brinton, M. C. 2009. Microclass mobility: Social reproduction in four countries. American Journal of Sociology, 114(4): 977-1036.

Joshi, A., Liao, H., \& Jackson, S. E. 2006. Cross-level effects of workplace diversity on sales performance and pay. Academy of Management Journal, 49(3): 459-481.

Joshi, A., Son, J., \& Roh, H. 2015. When can women close the gap? A meta-analytic test of sex differences in performance and rewards. Academy of Management Journal, 58(5): 15161545 .

Judge, T. A., \& Hurst, C. 2007. Capitalizing on one's advantages: Role of core self-evaluations. Journal of Applied Psychology, 92(5): 1212-1227.

Jung, J., \& Shin, T. 2019. Learning not to diversify: The transformation of graduate business education and the decline of diversifying acquisitions. Administrative Science Quarterly, 64(2): 337-369.

Kahn, L. M. 1978. Unions and wages: The effect of unions on the earnings of nonunion workers. ILR Review, 31(2): 205-216.

Kasser, T., Ryan, R. M., Zax, M., \& Sameroff, A. J. 1995. The relations of maternal and social environments to late adolescents' materialistic and prosocial values. Developmental Psychology, 31(6): 907-914. 
Katz, L. F., \& Murphy, K. M. 1992. Changes in relative wages, 1963-1987: supply and demand factors. The Quarterly Journal of Economics, 107(1): 35-78.

Kmec, J. A. 2003. Minority job concentration and wages. Social Problems, 50(1): 38-59.

Koenig, A. M., \& Eagly, A. H. 2014. Evidence for the social role theory of stereotype content: observations of groups' roles shape stereotypes. Journal of Personality and Social Psychology, 107(3): 371-389.

Kohn, M. L., \& Schooler, C. 1969. Class, occupation, and orientation. American Sociological Review, 34(5): 659-678.

Kraus, M. W., Côté, S., \& Keltner, D. 2010. Social class, contextualism, and empathic accuracy. Psychological Science, 21(11): 1716-1723.

Kraus, M. W., \& Tan, J. J. 2015. Americans overestimate social class mobility. Journal of Experimental Social Psychology, 58: 101-111.

Kraus, M. W., Park, J. W., \& Tan, J. J. 2017. Signs of social class: The experience of economic inequality in everyday life. Perspectives on Psychological Science, 12(3): 422-435.

Kraus, M. W., Piff, P. K., Mendoza-Denton, R., Rheinschmidt, M. L., \& Keltner, D. 2012. Social class, solipsism, and contextualism: How the rich are different from the poor.

Psychological Review, 119(3): 546-570.

Kraus, M. W., Piff, P. K., \& Keltner, D. 2009. Social class, sense of control, and social explanation. Journal of Personality and Social Psychology, 97(6): 992-1004.

Kristof-Brown, A. L., Zimmerman, R. D., \& Johnson, E. C. 2005. Consequences of individuals' fit at work: A meta-analysis of person-job, person-organization, person-group, and person-supervisor fit. Personnel Psychology, 58(2): 281-342.

Kusserow, A. 2004. American individualisms. Palgrave Macmillan, A Division of Nature America Incorporated.

Lareau, A. 2011. Unequal childhoods: Class, race, and family life. Berkeley: University of California Press.

Laurison, D., \& Friedman, S. 2016. The class pay gap in higher professional and managerial occupations. American Sociological Review, 81(4): 668-695.

Leana, C. R., \& Meuris, J. 2015. Living to work and working to live: Income as a driver of organizational behavior. Academy of Management Annals, 9(1), 55-95.

Levine, E. L., Ash, R. A., Hall, H., \& Sistrunk, F. 1983. Evaluation of job analysis methods by experienced job analysts. Academy of Management Journal, 26(2): 339-348. 
Lin, N. 1999. Social networks and status attainment. Annual Review of Sociology, 25(1): 467487.

Lin, K. H., \& Tomaskovic-Devey, D. 2013. Financialization and US income inequality, 19702008. American Journal of Sociology, 118(5): 1284-1329.

Liu, Y., \& Grusky, D. B. 2013. The payoff to skill in the third industrial revolution. American Journal of Sociology, 118(5): 1330-1374.

Markus, H. R., \& Conner, A. 2013. Clash!: 8 cultural conflicts that make us who we are. New York, NY: Hudson Street Press.

Markus, H. R., \& Kitayama, S. 2010. Cultures and selves: A cycle of mutual constitution. Perspectives on Psychological Science, 5(4): 420-430.

Martin, S. R., \& Côté, S. 2019. Social class transitioners: Their cultural abilities and organizational importance. Academy of Management Review, 44(3): 618-642.

Meindl, J. R., \& Ehrlich, S. B. 1987. The romance of leadership and the evaluation of organizational performance. Academy of Management Journal, 30(1): 91-109.

Meindl, J. R., Ehrlich, S. B., \& Dukerich, J. M. 1985. The romance of leadership. Administrative Science Quarterly, 30(1): 78-102.

Meyer, M. H. 2002. Care work: Gender, labor, and the welfare state. New York, NY: Routledge.

Miller, J. G., Kahle, S., \& Hastings, P. D. 2015. Roots and benefits of costly giving: Children who are more altruistic have greater autonomic flexibility and less family wealth. Psychological Science, 26(7): 1038-1045.

Mouw, T., \& Kalleberg, A. L. 2010. Occupations and the structure of wage inequality in the United States, 1980s to 2000s. American Sociological Review, 75(3): 402-431.

Nakao, K., \& Treas, J. 1994. Updating occupational prestige and socioeconomic scores: How the new measures measure up. Sociological Methodology, 24: 1-72.

Neuberg, S. L., \& Sng, O. 2013. A life history theory of social perception: Stereotyping at the intersections of age, sex, ecology (and race). Social Cognition, 31(6): 696-711.

Noe, R.A., Hollenbeck, J.R., Gerhart, B., Wright, P. 2000. Human resource management: Gaining a competitive advantage. Irwin McGraw-Hill: New York. 
O'Connor, J. S., Orloff, A. S., \& Shaver, S. 1999. States, markets, families: Gender, liberalism and social policy in Australia, Canada, Great Britain and the United States.

Cambridge: University Press.

Pearlin, L. I., \& Kohn, M. L. 1966. Social class, occupation, and parental values: A crossnational study. American Sociological Review, 31(4): 466-479.

Pfeffer, J. 1977a. Effects of an MBA and socioeconomic origins on business school graduates' salaries. Journal of Applied Psychology, 62(6): 698-705.

Pfeffer, J. 1977b. Toward an examination of stratification in organizations. Administrative Science Quarterly, 22: 553-567.

Piatak, J. S. 2015. Altruism by job sector: Can public sector employees lead the way in rebuilding social capital?. Journal of Public Administration Research and Theory, 25(3): 877-900.

Piazza, A., \& Castellucci, F. 2014. Status in organization and management theory. Journal of Management, 40(1): 287-315.

Piff, P. K. 2014. Wealth and the inflated self: Class, entitlement, and narcissism. Personality and Social Psychology Bulletin, 40(1): 34-43.

Piff, P. K., Kraus, M. W., Côté, S., Cheng, B. H., \& Keltner, D. 2010. Having less, giving more: The influence of social class on prosocial behavior. Journal of Personality and Social Psychology, 99(50): 771-786.

Piff, P. K., Kraus, M. W., \& Keltner, D. 2018. Unpacking the inequality paradox: The psychological roots of inequality and social class. In Advances in experimental social psychology (Vol. 57, pp. 53-124). Academic Press.

Piff, P. K., \& Robinson, A. R. 2017. Social class and prosocial behavior: Current evidence, caveats, and questions. Current Opinion in Psychology, 18: 6-10.

Piff, P. K., Stancato, D. M., Côté, S., Mendoza-Denton, R., \& Keltner, D. 2012. Higher social class predicts increased unethical behavior. Proceedings of the National Academy of Sciences, 109(11): 4086-4091.

Piff, P. K., Stancato, D. M., Martinez, A. G., Kraus, M. W., \& Keltner, D. 2012. Class, chaos, and the construction of community. Journal of Personality and Social Psychology, 103(6): 949-962.

Piketty, T., \& Saez, E. 2003. Income inequality in the United States, 1913-1998. The Quarterly Journal of Economics, 118(1): 1-41. 
Pitesa, M., \& Pillutla, M. M. 2019. Socioeconomic mobility and talent utilization of workers from poorer backgrounds: The overlooked importance of within-organization dynamics. Academy of Management Annals, 13(2): 737-769.

Powell, W. \& Steinberg, R. 2006. The nonprofit sector: A research handbook, 2nd ed. Yale University Press, New Haven, CT.

Ravitch, D. 2007. Why teacher unions are good for teachers and the public. American Educator. Retrieved from http://www.aft.org/newspubs/periodicals/ae/winter0607/ ravitch.cfm

Ridgeway, C. L. 2014. Why status matters for inequality. American Sociological Review, 79(1): $1-16$.

Rivera, L. A. 2012. Hiring as cultural matching: The case of elite professional service firms. American Sociological Review, 77(6): 999-1022.

Rivera, L. A. 2016. Pedigree: How elite students get elite jobs. Princeton, NJ: Princeton University Press.

Rivera, L. A., \& Tilcsik, A. 2016. Class advantage, commitment penalty: The gendered effect of social class signals in an elite labor market. American Sociological Review, 81(6): 10971131.

Robst, J. 2007. Education and job match: The relatedness of college major and work. Economics of Education Review, 26(4): 397-407.

Ros, M., Schwartz, S. H., \& Surkiss, S. 1999. Basic individual values, work values, and the meaning of work. Applied Psychology, 48(1): 49-71.

Rosen, S. 1986. The theory of equalizing differences. Handbook of Labor Economics, 1: 641692.

Rosenberg, M., \& Pearlin, L. I. 1978. Social class and self-esteem among children and adults. American Journal of Sociology, 84(1): 53-77.

Rucker, D. D., Galinsky, A. D., \& Magee, J. C. 2018. The Agentic-Communal Model of Advantage and Disadvantage: How inequality produces similarities in the psychology of power, social class, gender, and race. In Advances in experimental social psychology (Vol. 58, pp. 71-125). Academic Press.

Salamon, L. M., \& Newhouse, C.L., 2020. The 2020 nonprofit employment report, Nonprofit Economic Data Bulletin, 48: 1-23.

Shaw, J. D. 2014. Pay dispersion. Annual Review of Organizational Psychology and Organizational Behavior, 1(1): 521-544. 
Shubert, M. 2014. Emotional intelligence in nonprofit hiring practices: A new criterion. Unpublished doctoral dissertation, University of Tennessee at Chattanooga.

Singelis, T. M. 1994. The measurement of independent and interdependent self-construals. Personality and Social Psychology Bulletin, 20(5): 580-591.

Smith, T. W., \& Son, J. 2014. Measuring Occupational Prestige on the 2012 General Social Survey (GSS Methodological Report No. 122). Chicago: National Opinion Research Center.

Solon, G. 1992. Intergenerational income mobility in the United States. The American Economic Review: 393-408.

Sørensen, A. B. 2000. Toward a sounder basis for class analysis. American Journal of Sociology, 105(6): 1523-1558.

Soria, K. M., Hussein, D., \& Vue, C. 2014. Leadership for whom? Socioeconomic factors predicting undergraduate students' positional leadership participation. Journal of Leadership Education, 13: 14 - 40.

Stainback, K., Tomaskovic-Devey, D., \& Skaggs, S. 2010. Organizational approaches to inequality: Inertia, relative power, and environments. Annual Review of Sociology, 36: 225-247.

Staw, B. M., Sandelands, L. E., \& Dutton, J. E. 1981. Threat rigidity effects in organizational behavior: A multilevel analysis. Administrative Science Quarterly, 26(4): 501-524.

Stellar, J. E., Manzo, V. M., Kraus, M. W., \& Keltner, D. 2012. Class and compassion: Socioeconomic factors predict responses to suffering. Emotion, 12(3): 449-459.

Stephens, N. M., Dittmann, A. G., \& Townsend, S. S. M. 2017. Social class and models of competence: How gateway institutions disadvantage working-class Americans and how to intervene. In C. Dweck, A. Elliot, \& D. Yeager (Eds.), Handbook of competence and motivation (2nd ed.): Theory and application. New York, NY: Guilford Press.

Stephens, N. M., Hamedani, M. G., \& Destin, M. 2014. Closing the social-class achievement gap: A difference-education intervention improves first-generation students' academic performance and all students' college transition. Psychological Science, 25(4): 943-953.

Stephens, N. M., \& Townsend, S. S. 2013. Rank is not enough: Why we need a sociocultural perspective to understand social class. Psychological Inquiry, 24(2): 126-130.

Stern, I., \& Westphal, J. D. 2010. Stealthy footsteps to the boardroom: Executives' backgrounds, sophisticated interpersonal influence behavior, and board appointments. Administrative Science Quarterly, 55(2): 278-319. 
Themudo, N. S. 2009. Gender and the nonprofit sector. Nonprofit and Voluntary Sector Quarterly, 38(4): 663-683.

Tilcsik, A., Anteby, M., \& Knight, C. R. 2015. Concealable stigma and occupational segregation: Toward a theory of gay and lesbian occupations. Administrative Science Quarterly, 60(3): 446-481.

Torche, F. 2011. Is a college degree still the great equalizer? Intergenerational mobility across levels of schooling in the United States. American Journal of Sociology, 117(3): 763807.

Torche, F. 2015. Analyses of intergenerational mobility: An interdisciplinary review. The ANNALS of the American Academy of Political and Social Science, 657(1): 37-62.

Trejo, S. 2016. An econometric analysis of the major choice of first-generation college students. The Developing Economist, 3(1): Retrieved from http://www.inquiriesjournal.com/a?id=1407

U.S. Bureau of Labor Statistics. 2019. The United States Department of Labor. Washington, D.C. Retrieved at https://www.bls.gov/oes/current/oes_nat.htm.

Varnum, M. E. 2015. Higher in status, (even) better-than-average. Frontiers in Psychology, 6: $496-503$.

Vornovitsky, M., Gottschalck A., and Smith. A. 2014. "Distribution of Household Wealth in the U.S.: 2000 to 2011.” Technical report, U.S. Census Bureau, Washington, DC.

Wang, Z., Jetten, J., \& Steffens, N. K. 2020. The more you have, the more you want? Higher social class predicts a greater desire for wealth and status. European Journal of Social Psychology, 50(2): 360-375.

Warren, J. R., Sheridan, J. T., \& Hauser, R. M. 2002. Occupational stratification across the life course: Evidence from the Wisconsin Longitudinal Study. American Sociological Review, 67(3): 432-455.

Weeden, K. A., \& Grusky, D. B. 2005. The case for a new class map. American Journal of Sociology, 111(1): 141-212.

Weeden, K. A., \& Grusky, D. B. 2012. The three worlds of inequality. American Journal of Sociology, 117(6): 1723-1785.

Weeden, K. A., Kim, Y. M., Di Carlo, M., \& Grusky, D. B. 2007. Social class and earnings inequality. American Behavioral Scientist, 50(5): 702-736. 
Williams, J. C., Multhaup, M., \& Mihaylo, S. 2018. Why companies should add class to their diversity discussions. Harvard Business Review. Retrieved from https://hbr.org/2018/09/why-companies-should-add-class-to-their-diversity-discussions.

Wodtke, G. T. 2016. Social class and income inequality in the United States: Ownership, authority, and personal income distribution from 1980 to 2010. American Journal of Sociology, 121(5): 1375-1415.

Word, J., \& Park, S. M. 2009. Working across the divide: Job involvement in the public and nonprofit sectors. Review of Public Personnel Administration, 29(2): 103-133.

Wright, E. O. 1978. Race, class, and income inequality. American Journal of Sociology, 83(6): 1368-1397.

Zhou, X. 2005. The institutional logic of occupational prestige ranking: Reconceptualization and reanalyses. American Journal of Sociology, 111(1): 90-140. 
TABLE 1. Summary of measures used in the GSS and NLSY97 studies

\begin{tabular}{|c|c|c|}
\hline Variables & Description & Data source \\
\hline Social class origin & $\begin{array}{l}\text { Respondent family income when } 16 \text { years old } \\
\text { Average parental income from 1997-2001 } \\
\text { Highest year of school completed by mother and father } \\
\text { Mother and father's occupational prestige score }\end{array}$ & $\begin{array}{l}\text { GSS: income16 } \\
\text { NLSY97: R1204500, } \\
\text { R2563300, R3884900, } \\
\text { R5464100, R7227800 } \\
\text { GSS: maeduc, paeduc; } \\
\text { NLSY97: R1302400, } \\
\text { R1302500 } \\
\text { GSS: mapres10, papres10 }\end{array}$ \\
\hline Work autonomy & $\begin{array}{l}\text { Decision-making freedom } \\
\text { Freedom to determine own tasks, priorities, and goals } \\
\text { Developing one's own way of working and depending } \\
\text { on oneself to get things done }\end{array}$ & $\begin{array}{l}\text { O*NET: 4.C.3.a.4 } \\
\text { O*NET: } 4 . C .3 . b .8 \\
\text { O*NET: } 1 . C .6\end{array}$ \\
\hline Prosocial orientation & $\begin{array}{l}\text { Social interest } \\
\text { Nonprofit orientation }\end{array}$ & $\begin{array}{l}\text { O*NET: 1.B.1.d } \\
\text { BLS: } \\
\text { www.bls.gov/bdm/nonpro } \\
\text { fits/nonprofits.htm }\end{array}$ \\
\hline Personal income & $\begin{array}{l}\text { Respondent income adjusted to } 2010 \text { dollars } \\
\text { Average personal income from } 2010 \text { to } 2017\end{array}$ & $\begin{array}{l}\text { GSS: conrinc } \\
\text { NLSY97: U2857200, } \\
\text { U2857300, U0956900, } \\
\text { U0957000, T8976700, } \\
\text { T8976800, T7545600, } \\
\text { T7545700, T6055500, } \\
\text { T6055600 }\end{array}$ \\
\hline $\begin{array}{l}\text { Sociodemographic } \\
\text { control variables }\end{array}$ & & \\
\hline Race & $\begin{array}{l}80 \% \text { White, } 14 \% \text { Black, } 6 \% \text { other } \\
59 \% \text { White, } 27 \% \text { Black, } 9 \% \text { Hispanic, } 2 \% \text { Asian, } 1 \% \\
\text { Native, } 1 \% \text { Mixed, and } 2 \% \text { "other" }\end{array}$ & $\begin{array}{l}\text { GSS: race } \\
\text { NLSY97: R1115400 }\end{array}$ \\
\hline Gender & $1=$ female, $0=$ male & $\begin{array}{l}\text { GSS: sex; NLSY97: } \\
\text { R0536300 }\end{array}$ \\
\hline Age & 25 to 69 years old & GSS: age \\
\hline Immigrant status & $1=$ born in U.S., $0=$ born outside U.S. & $\begin{array}{l}\text { GSS: born; NLSY97: } \\
\text { R1201300 }\end{array}$ \\
\hline $\begin{array}{l}\text { Parental work } \\
\text { autonomy }\end{array}$ & measured in the same way as personal work autonomy & \\
\hline
\end{tabular}




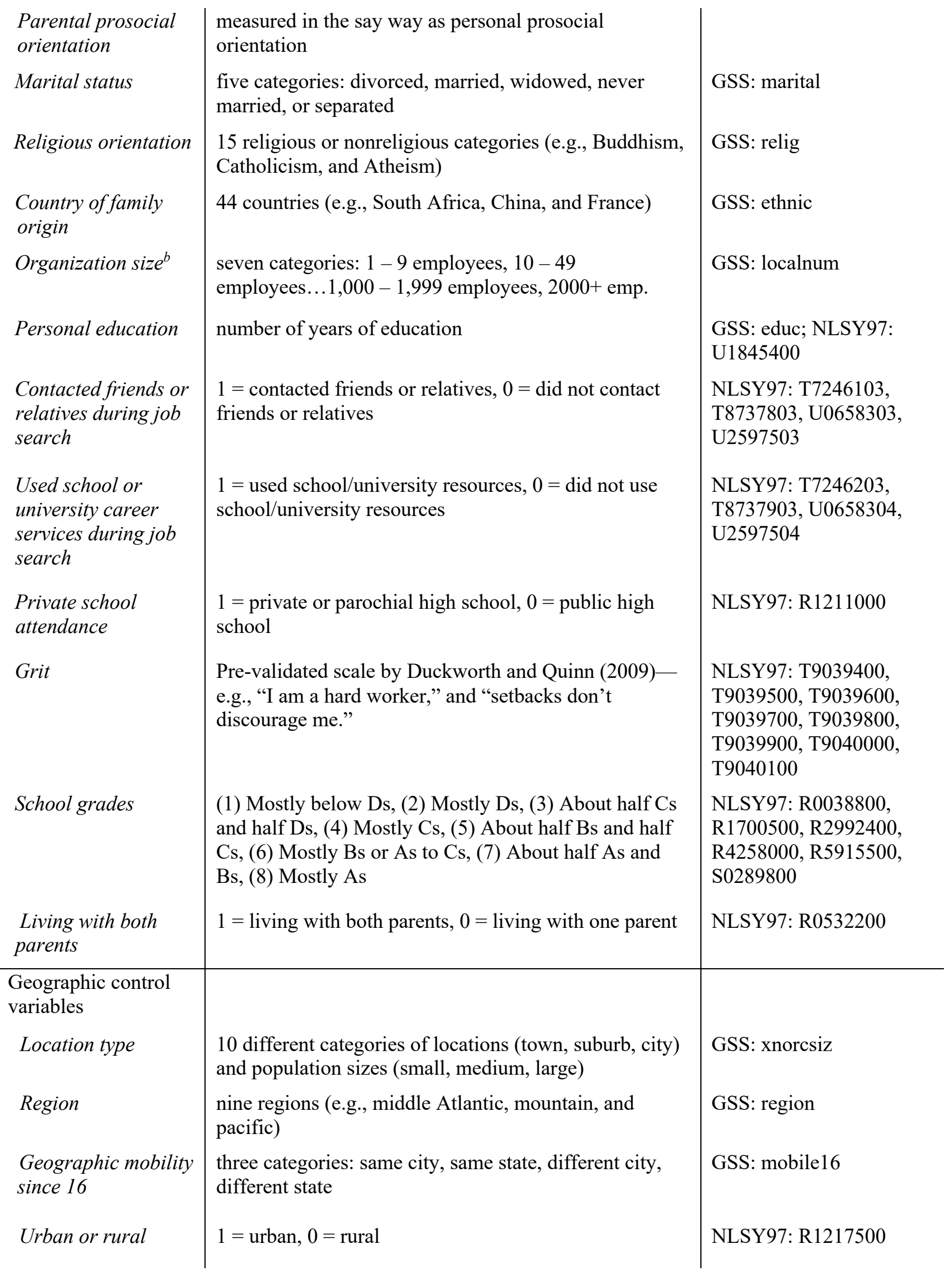




\begin{tabular}{|c|c|c|}
\hline $\begin{array}{l}\text { Occupational control } \\
\text { variables }\end{array}$ & & \\
\hline $\begin{array}{l}\text { Occupational } \\
\text { prestige }\end{array}$ & $\begin{array}{l}\text { A nationally representative sample of U.S. adults } \\
\text { judged the prestige of } 2010 \text { Census occupations: } \\
\text { https://gss.norc.org/Documents/reports/methodological- } \\
\text { reports/MR122\%20Occupational\%20Prestige.pdf }\end{array}$ & GSS: prestg10 \\
\hline $\begin{array}{l}\text { Relationship } \\
\text { importance }^{c}\end{array}$ & $\begin{array}{l}\text { How important is preferring to work with others and } \\
\text { being personally connected with others to the } \\
\text { performance of your current job? }(1=\text { not important, } 5= \\
\text { very important })\end{array}$ & O*NET: 1.C.3.c \\
\hline Preparation level $^{d}$ & $\begin{array}{l}\text { One of five levels based on the required education, } \\
\text { related experience, and on-the-job training necessary to } \\
\text { perform tasks associated with the occupation }(1=\text { little } \\
\text { or no preparation, } 5=\text { extensive preparation })\end{array}$ & $\begin{array}{l}\text { O*NET: } \\
\text { www.onetonline.org/help/ } \\
\text { online/zones }\end{array}$ \\
\hline Verbal skill ${ }^{e}$ & $\begin{array}{l}\text { The extent to which the following abilities are required } \\
\text { in the occupation: oral comprehension, written } \\
\text { comprehension, oral expression, written expression, } \\
\text { reading comprehension, writing, and speaking }(\alpha=.95)\end{array}$ & $\begin{array}{l}\text { O*NET: 1.A.1.a.1, } \\
\text { 1.A.1.a.2, 1.A.1.a.3, } \\
\text { 1.A.1.a.4, 2.A.1.a, } \\
\text { 2.A.1.b, 2.A.1.c }\end{array}$ \\
\hline Quantitative skille & $\begin{array}{l}\text { The extent to which the following abilities are required } \\
\text { in the occupation: Mathematical reasoning, number } \\
\text { facility, and mathematical knowledge }(\alpha=.81)\end{array}$ & $\begin{array}{l}\text { O*NET: 1.A.1.c.1, } \\
\text { 1.A.1.c.2, 2.C.4.a }\end{array}$ \\
\hline $\begin{array}{l}\text { Proportion of } \\
\text { female workers }\end{array}$ & Ratio of female workers to the total number of workers & $\begin{array}{l}\text { BLS: } \\
\text { www.bls.gov/cps/cpsaat1 } \\
\text { 1.htm }\end{array}$ \\
\hline $\begin{array}{l}\text { Proportion of } \\
\text { minority workers }\end{array}$ & $\begin{array}{l}\text { Ratio of minority workers to the total number of } \\
\text { workers }\end{array}$ & $\begin{array}{l}\text { BLS: } \\
\text { www.bls.gov/cps/cpsaat1 } \\
\text { 1.htm }\end{array}$ \\
\hline
\end{tabular}

Note: Survey year was dummy-coded and analyzed as fixed effects.

We conducted a confirmatory factor analysis (at the occupation level) to verify the factor structure of multi-item occupational characteristics: work autonomy (3 items), prosocial orientation ( 2 items), verbal skill ( 7 items), and quantitative skill ( 3 items). We entered all 15 items into a four-factor model. This model indicated adequate fit for the four-factor model $\left(\chi^{2}=2551.84, d f=84, p<.001\right.$, RMSEA $=.07$; $\mathrm{CFI}=.90, \mathrm{TLI}=.87)$. Combining all items into a competing one-factor model produced significantly inferior fit $\left(\chi^{2}=8211.69, d f=90, p<.001, \mathrm{RMSEA}=.16, \mathrm{CFI}=.65, \mathrm{TLI}=.60 ; \Delta \chi^{2}=5659.85, d f=6, p\right.$ $<.001)$. A two-factor model in which work autonomy and prosocial orientation items load onto one factor and verbal and quantitative skill items load onto another factor also produced significantly inferior fit $\left(\chi^{2}\right.$ $\left.=7498.80, d f=89, p<.001, \mathrm{RMSEA}=.14, \mathrm{CFI}=.68, \mathrm{TLI}=.63 ; \Delta \chi^{2}=3108.01, d f=5, p<.001\right)$.

${ }^{a}$ The BLS provides data on the proportion of employees working for nonprofit organizations in each industry. The BLS also provides employment numbers by industry and occupation. To construct our measure, we multiplied (a) the number of people in each occupation per industry by $(b)$ the proportion of people who work in the nonprofit sector in each industry to arrive at (c) the number of people in each occupation that works in the nonprofit sector per industry. Next, we summed the number of people in each occupation who work in the nonprofit sector across industries and divided that by the total number of people in each occupation. For example, assume a world with only three industries (finance, 
agriculture, and education) and that $10 \%$ of the finance workers, $20 \%$ of agriculture workers, and $30 \%$ of education workers are in the nonprofit sector. If there are 100 accountants in this world and 50 of them work in finance, 20 in agriculture, and 30 in education, then the proportion of accountants working in nonprofit would be $.18[(50 \times .10+20 \times .20+30 \times .30) / 100]$. Our measure assumes that for-profit and nonprofit establishments have similar occupational staffing patterns within industries, but because BLS provides data on 72 narrow industry groups, our measure was more accurate. For example, the BLS separates the broader education industry into seven narrow categories (e.g., "junior colleges," "colleges, universities, and professional schools," and "business schools and computer and management") and provides nonprofit employment numbers for each category.

${ }^{\mathrm{b}}$ GSS respondents were asked to report this information only beginning in 1989 , leading to 18,508 valid responses. To maintain a larger sample size in our primary analyses, we did not include organization size as a control variable. However, we controlled for organization size as a robustness check and our substantive conclusions remained the same.

${ }^{c}$ Occupations high on relationship importance include guidance counselors, flight attendants, and healthcare social workers. Occupations low on relationship importance include writers, computer hardware engineers, and economists.

${ }^{\mathrm{d}}$ High preparation level includes education administrators, chief executives, and general managers. Low preparation level includes baristas, dishwashers, and sewing machine operators.

${ }^{\mathrm{e}}$ Each indicator of verbal and quantitative skill was the standardized average of two items that assessed the importance $(1=$ not important, $5=$ extremely important $)$ and level $(1=$ lowest level, $7=$ highest level $)$ of each ability. As an example, for "mathematical knowledge," job incumbents were asked "how important is knowledge of arithmetic, algebra, geometry, calculus, statistics, and their applications to the performance of your current job?" and "what level of knowledge of arithmetic, algebra, geometry, calculus, statistics, and their applications is needed to perform your current job?" 
TABLE 2. Correlation matrix for individual-level analyses of GSS participants

\begin{tabular}{|c|c|c|c|c|c|c|c|c|c|c|c|c|c|}
\hline Variables & $\mathrm{M}$ & SD & 1. & 2. & 3. & 4. & 5. & 6. & 7. & 8. & 9. & 10. & 11. \\
\hline 1. Personal income & 35.13 & 34.30 & & & & & & & & & & & \\
\hline 2. Class origin & .00 & .80 & .18 & & & & & & & & & & \\
\hline 3. Parental education & 10.86 & 3.69 & .16 & .79 & & & & & & & & & \\
\hline 4. Parental prestige & 43.06 & 11.50 & .13 & .79 & .44 & & & & & & & & \\
\hline 5. Parental income & 2.76 & .88 & .11 & .74 & .33 & .27 & & & & & & & \\
\hline 6. Work autonomy & 4.02 & .38 & .28 & .19 & .18 & .15 & .11 & & & & & & \\
\hline 7. Prosocial orientation & .01 & .94 & -.04 & .13 & .14 & .10 & .06 & .29 & & & & & \\
\hline 8. Education & 13.24 & 3.07 & .32 & .44 & .50 & .29 & .24 & .35 & .36 & & & & \\
\hline 9. Occupation prestige & 43.85 & 12.88 & .33 & .26 & .25 & .21 & .14 & .54 & .48 & .52 & & & \\
\hline 10. Parental autonomy & 3.99 & .32 & .07 & .41 & .19 & .54 & .15 & .10 & .06 & .13 & .12 & & \\
\hline 11. Parental prosociality & -.01 & .81 & .08 & .48 & .40 & .51 & .15 & .12 & .12 & .26 & .16 & .36 & \\
\hline $\begin{array}{l}\text { 12. Immigrant status }(1= \\
\text { immigrant) }\end{array}$ & .91 & .29 & -.01 & .06 & .13 & -.04 & .06 & .02 & .01 & .02 & .01 & -.05 & -.06 \\
\hline 13. Gender $(1=$ female $)$ & .54 & .50 & -.27 & -.01 & -.01 & -.02 & .00 & -.06 & .32 & -.02 & -.05 & -.02 & .00 \\
\hline 14. Black $(1=$ Black $)$ & .14 & .35 & -.10 & -.16 & -.09 & -.14 & -.15 & -.10 & .01 & -.10 & -.12 & -.08 & -.02 \\
\hline 15. White $(1=$ White $)$ & .80 & .40 & .09 & .18 & .12 & .13 & .17 & .10 & .00 & .10 & .12 & .07 & .01 \\
\hline 16. Age & 44.45 & 12.32 & .13 & -.19 & -.25 & -.09 & -.10 & .02 & -.01 & -.14 & -.01 & .01 & -.09 \\
\hline 17. Relational importance & 3.19 & 1.15 & -.04 & .09 & .11 & .06 & .05 & .25 & .70 & .23 & .26 & .04 & .09 \\
\hline 18. Verbal skill & -.15 & .89 & .32 & .31 & .30 & .23 & .18 & .62 & .46 & .56 & .79 & .13 & .18 \\
\hline 19. Quantitative skill & -.16 & .88 & .30 & .20 & .19 & .15 & .12 & .35 & .05 & .36 & .56 & .09 & .10 \\
\hline 20. Preparation level & 2.81 & 1.02 & .38 & .28 & .27 & .22 & .15 & .59 & .36 & .54 & .75 & .13 & .17 \\
\hline 21. Proportion minority & .22 & .08 & -.23 & -.18 & -.16 & -.13 & -.13 & -.44 & .01 & -.24 & -.39 & -.09 & -.07 \\
\hline 22. Proportion women & .38 & .26 & -.19 & .05 & .05 & .02 & .04 & .05 & .56 & .13 & .07 & .01 & .06 \\
\hline
\end{tabular}

(Table 2 continues below) 
TABLE 2. Correlation matrix for individual-level analyses of GSS participants (continued)

\begin{tabular}{|c|c|c|c|c|c|c|c|c|c|c|}
\hline Variables & 12. & 13. & 14. & 15 . & 16. & 17. & 18. & 19. & 20. & 21. \\
\hline \multicolumn{11}{|l|}{$\begin{array}{l}\text { 12. Immigrant status }(1= \\
\text { immigrant) }\end{array}$} \\
\hline 13. Gender $(1=$ female $)$ & .01 & & & & & & & & & \\
\hline 14. Black $(1=$ Black $)$ & .02 & .05 & & & & & & & & \\
\hline 15. White $(1=$ White $)$ & .21 & -.04 & -.82 & & & & & & & \\
\hline 16. Age & .05 & .00 & -.03 & .07 & & & & & & \\
\hline 17. Relational importance & .02 & .35 & .00 & .01 & -.03 & & & & & \\
\hline 18. Verbal skill & .03 & .07 & -.16 & .15 & -.01 & .37 & & & & \\
\hline 19. Quantitative skill & .01 & -.08 & -.15 & .14 & -.01 & .07 & .63 & & & \\
\hline 20. Preparation level & .01 & -.10 & -.13 & .12 & .00 & .15 & .77 & .58 & & \\
\hline 21. Proportion minority & -.08 & .18 & .21 & -.21 & .00 & .01 & -.51 & -.41 & -.45 & \\
\hline 22. Proportion women & .00 & .63 & .03 & -.02 & -.02 & .58 & .24 & -.07 & -.03 & .16 \\
\hline
\end{tabular}

Note: $N=22,944$ to 43,793 due to missing values and smaller sample size with personal and parental income. In addition to the control variables included in this table, our regression analysis also controls for geographic region, location type, religious orientation, marital status, survey year, and country of family origin (see Table 1 for details). 
TABLE 3. Multiple regression analyses predicting work autonomy and prosocial orientation (H1 and H2; GSS data)

\begin{tabular}{|c|c|c|c|c|}
\hline \multirow[b]{2}{*}{ Variable } & \multicolumn{2}{|c|}{$\begin{array}{l}\text { Model 1: } \\
\text { Work } \\
\text { autonomy }\end{array}$} & \multicolumn{2}{|c|}{$\begin{array}{c}\text { Model 2: } \\
\text { Prosocial } \\
\text { orientation }\end{array}$} \\
\hline & $\beta$ & se & $\beta$ & se \\
\hline Class origin & .019 & .006 & -.044 & .006 \\
\hline Female & -.122 & .011 & .317 & .009 \\
\hline White & .037 & .032 & .010 & .026 \\
\hline Black & -.008 & .040 & .065 & .032 \\
\hline Age & .046 & .007 & .020 & .005 \\
\hline Personal education & .057 & .008 & .130 & .006 \\
\hline Occupational prestige & .429 & .006 & .300 & .005 \\
\hline Parental work autonomy & .022 & .005 & -.001 & .005 \\
\hline Parental prosocial orientation & -.000 & .006 & .017 & .005 \\
\hline Relationship importance & .140 & .005 & .552 & .005 \\
\hline Born in U.S. & .056 & .021 & -.014 & .020 \\
\hline Move to different city, same state & .020 & .013 & .002 & .011 \\
\hline Move to different state & -.001 & .013 & -.005 & .011 \\
\hline$R^{2}$ & \multicolumn{2}{|c|}{.33} & \multicolumn{2}{|c|}{.61} \\
\hline$F$ value & \multicolumn{2}{|c|}{90.51} & \multicolumn{2}{|c|}{293.20} \\
\hline
\end{tabular}

Note: $\mathrm{N}=22,484$ after listwise deletion of missing values, $d f=22,365$. Bolded values reflect $p<.05$. Analyses also control for geographic region, location type, religious orientation, marital status, survey year, and country of family origin. 
TABLE 4. Multiple regression analyses predicting personal income (GSS data)

\begin{tabular}{llllll}
\hline $\begin{array}{l}\text { Variables included with } \\
\text { class origins }\end{array}$ & $\begin{array}{l}\text { Coefficient } \\
\text { for class } \\
\text { origins }\end{array}$ & $\begin{array}{l}\text { Standard } \\
\text { error }\end{array}$ & $R^{2}$ & $F$ value & $d f$ \\
\hline Model 1: No controls & 6.32 & .250 & .03 & 638.60 & 22,482 \\
$\begin{array}{l}\text { Model 2: Occupations as } \\
\text { fixed effects }\end{array}$ & 2.01 & .232 & .29 & 19.02 & 22,025 \\
$\begin{array}{l}\text { Model 3: Work autonomy } \\
\text { and prosocial orientation }\end{array}$ & 4.97 & .244 & .11 & 882.60 & 22,480 \\
\end{tabular}

Note: $\mathrm{N}=22,484$. 
TABLE 5. Multiple regression analyses predicting personal income (H3, GSS data)

\begin{tabular}{|c|c|c|c|c|c|c|c|c|}
\hline \multirow[b]{2}{*}{ Variable } & \multicolumn{2}{|c|}{$\begin{array}{c}\text { Model 1: } \\
\text { Basic } \\
\text { demographics }\end{array}$} & \multicolumn{2}{|c|}{$\begin{array}{c}\text { Model 2: } \\
\text { Education and } \\
\text { prestige }\end{array}$} & \multicolumn{2}{|c|}{$\begin{array}{c}\text { Model 3: } \\
\text { Autonomy and } \\
\text { prosociality }\end{array}$} & \multicolumn{2}{|c|}{$\begin{array}{c}\text { Model 4: } \\
\text { Other controls }\end{array}$} \\
\hline & $\beta$ & se & $\beta$ & se & $\beta$ & se & $\beta$ & se \\
\hline Intercept & 47.28 & .95 & 43.77 & .90 & 40.43 & .88 & 43.93 & 4.00 \\
\hline Class origin & 7.05 & .30 & 2.22 & .29 & 1.63 & .29 & 1.20 & .29 \\
\hline Female & -18.58 & .45 & -18.77 & .42 & -13.72 & .45 & -12.90 & .51 \\
\hline White & -1.37 & .96 & -.99 & .90 & -1.06 & .88 & 2.24 & 1.20 \\
\hline Black & -6.54 & 1.12 & -4.35 & 1.05 & -3.24 & 1.03 & 1.42 & 1.50 \\
\hline Age & 6.32 & .25 & 5.63 & .24 & 5.48 & .23 & 4.01 & .25 \\
\hline Parental work autonomy & -.49 & .26 & -.20 & .24 & -.23 & .24 & .03 & .23 \\
\hline Parental prosocial orientation & .28 & .25 & -.56 & .24 & -.33 & .23 & -.48 & .23 \\
\hline Personal education & & & 8.05 & .29 & 9.12 & .29 & 7.16 & .30 \\
\hline Occupational prestige & & & 7.18 & .25 & 8.14 & .28 & 3.79 & .38 \\
\hline Work autonomy & & & & & 4.12 & .26 & 2.10 & .29 \\
\hline Prosocial orientation & & & & & -7.01 & .25 & -7.35 & .35 \\
\hline Move to dif. city, same state & & & & & & & .72 & .51 \\
\hline Move to different state & & & & & & & .50 & .50 \\
\hline Proportion female & & & & & & & -2.34 & .33 \\
\hline Proportion minority & & & & & & & 1.29 & .26 \\
\hline Preparation level & & & & & & & 3.85 & .37 \\
\hline Verbal skill & & & & & & & 4.07 & .55 \\
\hline Quantitative skill & & & & & & & .30 & .32 \\
\hline Relationship importance & & & & & & & 2.35 & .30 \\
\hline Born in U.S. & & & & & & & .11 & .90 \\
\hline$R^{2}$ & \multicolumn{2}{|c|}{.13} & \multicolumn{2}{|c|}{.23} & \multicolumn{2}{|c|}{.26} & \multicolumn{2}{|c|}{.31} \\
\hline$F$ value & \multicolumn{2}{|c|}{462.70} & \multicolumn{2}{|c|}{747.90} & \multicolumn{2}{|c|}{730.80} & \multicolumn{2}{|c|}{79.97} \\
\hline$d f$ & \multicolumn{2}{|c|}{22,476} & \multicolumn{2}{|c|}{22,474} & \multicolumn{2}{|c|}{22,472} & \multicolumn{2}{|c|}{22,385} \\
\hline
\end{tabular}

Note: $\mathrm{N}=22,484$. Bolded values reflect $p<.05$. Model 4 includes controls for geographic region, location type, religious orientation, marital status, survey year, and country of family origin. 
TABLE 6. Multiple regression analyses predicting work autonomy (H1, NLSY97 data)

\begin{tabular}{|c|c|c|c|c|c|c|}
\hline \multirow[b]{2}{*}{ Variable } & \multicolumn{2}{|c|}{ Model 1} & \multicolumn{2}{|c|}{ Model 2} & \multicolumn{2}{|c|}{ Model 3} \\
\hline & $\beta$ & se & $\beta$ & se & $\beta$ & se \\
\hline Class origin & .052 & .014 & & & & \\
\hline Parental income & & & .039 & .013 & & \\
\hline Parental education & & & & & .045 & .014 \\
\hline Female & -.043 & .024 & -.047 & .025 & -.045 & .025 \\
\hline Age & .016 & .111 & .011 & .011 & .016 & .011 \\
\hline Personal education & .051 & .015 & .055 & .015 & .056 & .016 \\
\hline Occupational prestige & .493 & .013 & .497 & .013 & .491 & .013 \\
\hline Relationship importance & .088 & .012 & .085 & .013 & .086 & .016 \\
\hline Job from friends or relatives & -.072 & .026 & -.074 & .027 & -.080 & .027 \\
\hline Job from school resources & .058 & .068 & .074 & .072 & .063 & .069 \\
\hline Private school attendance & -.006 & .045 & .003 & .046 & -.005 & .046 \\
\hline Grit & .045 & .011 & .039 & .011 & .046 & .011 \\
\hline School grades & .031 & .013 & .038 & .013 & .030 & .013 \\
\hline Lived with both parents & .018 & .024 & .012 & .025 & .030 & .024 \\
\hline Native citizen & -.064 & .037 & -.059 & .037 & -.062 & .039 \\
\hline Urban location & -.009 & .026 & -.008 & .027 & .002 & .027 \\
\hline$R^{2}$ & & & & & & \\
\hline$F$ value & & 30 & & & & \\
\hline$d f$ & & & & & & \\
\hline
\end{tabular}

Note: $\mathrm{N}=5,042-5,322$ due to missing values for parental education and parental income. Bolded values reflect $p<.05$. Analyses control for race (Asian, Black, Hispanic, Mixed, Native, White, and "other"). 
TABLE 7. Multiple regression analyses predicting prosocial orientation (H2, NLSY97 data)

\begin{tabular}{|c|c|c|c|c|c|c|}
\hline \multirow[b]{2}{*}{ Variable } & \multicolumn{2}{|c|}{ Model 1} & \multicolumn{2}{|c|}{ Model 2} & \multicolumn{2}{|c|}{ Model 3} \\
\hline & $\beta$ & se & $\beta$ & se & $\beta$ & se \\
\hline Class origin & -.043 & .011 & & & & \\
\hline Parental income & & & -.046 & .010 & & \\
\hline Parental education & & & & & -.025 & .011 \\
\hline Female & .271 & .019 & .276 & .019 & 271 & .019 \\
\hline Age & -.013 & .009 & -.008 & .009 & -.017 & .009 \\
\hline Personal education & .071 & .012 & .067 & .012 & .061 & .012 \\
\hline Occupational prestige & .312 & .010 & .310 & .010 & .315 & .011 \\
\hline Relationship importance & .581 & .010 & .578 & .010 & .579 & .010 \\
\hline Job from friends or relatives & -.017 & .020 & -.012 & .021 & -.014 & .021 \\
\hline Job from school resources & -.049 & .054 & -.054 & .056 & -.059 & .054 \\
\hline Private school attendance & -.014 & .035 & -.018 & .036 & -.029 & .036 \\
\hline Grit & -.028 & .009 & -.027 & .009 & -.031 & .009 \\
\hline School grades & -.016 & .010 & -.020 & .010 & -.016 & .010 \\
\hline Lived with both parents & .020 & .019 & .029 & .019 & -.008 & .020 \\
\hline Native citizen & .045 & .029 & .044 & .029 & .052 & .032 \\
\hline Urban location & -.011 & .020 & -.009 & .021 & -.017 & .022 \\
\hline$R^{2}$ & & 1 & & & & \\
\hline$F$ value & & .90 & & & & \\
\hline$d f$ & & 01 & & & & \\
\hline
\end{tabular}

Note: $\mathrm{N}=5,042-5,322$ due to missing values of parental education and parental income. Bolded values reflect $p<.05$. Analyses control for race (Asian, Black, Hispanic, Mixed, Native, White, and "other"). 
TABLE 8. Multiple regression analyses predicting personal income (H3, NLSY97 data)

\begin{tabular}{|c|c|c|c|c|c|c|}
\hline \multirow[b]{2}{*}{ Variable } & \multicolumn{2}{|c|}{$\begin{array}{c}\text { Model 1: } \\
\text { Education and } \\
\text { prestige }\end{array}$} & \multicolumn{2}{|c|}{$\begin{array}{l}\text { Model 2: } \\
\text { Add autonomy } \\
\text { and prosocial }\end{array}$} & \multicolumn{2}{|c|}{$\begin{array}{l}\text { Model 3: } \\
\text { Add other } \\
\text { controls }\end{array}$} \\
\hline & $\beta$ & se & $\beta$ & se & $\beta$ & se \\
\hline Intercept & 54.84 & 2.67 & 51.89 & 2.62 & 51.68 & 2.74 \\
\hline Class origin & 4.27 & .39 & 3.81 & .37 & 3.77 & .39 \\
\hline Female & -13.51 & .65 & -9.65 & .69 & -9.11 & .77 \\
\hline Age & 2.35 & .32 & 2.22 & .31 & 2.19 & .31 \\
\hline Personal education & 7.07 & .41 & 7.39 & .41 & 5.98 & .45 \\
\hline Occupational prestige & 6.26 & .38 & 7.41 & .45 & 4.47 & .56 \\
\hline Work autonomy & & & 2.37 & .39 & .96 & .41 \\
\hline Prosocial orientation & & & -5.64 & .39 & -5.26 & .57 \\
\hline Relationship importance & & & & & 1.57 & .50 \\
\hline Job from friends or relatives & & & & & -3.22 & .74 \\
\hline Job from school resources & & & & & -2.14 & 1.92 \\
\hline Private school attendance & & & & & -1.21 & 1.26 \\
\hline Grit & & & & & 1.62 & .32 \\
\hline School grades & & & & & 1.47 & .37 \\
\hline Lived with both parents & & & & & .96 & .68 \\
\hline Native citizen & & & & & -3.87 & 1.05 \\
\hline Urban location & & & & & .81 & .74 \\
\hline Proportion female & & & & & -3.04 & .51 \\
\hline Proportion minority & & & & & .39 & .38 \\
\hline Preparation level & & & & & .31 & .58 \\
\hline Verbal skill & & & & & 3.93 & .68 \\
\hline Quantitative skill & & & & & 1.29 & .45 \\
\hline$R^{2}$ & .3 & & .3 & & & \\
\hline$F$ value & 224 & & 218 & & & \\
\hline$d f$ & 5,3 & & 5,3 & & & \\
\hline
\end{tabular}

Note: $\mathrm{N}=5,322$ after listwise deletion. Bolded values reflect $p<.05$. Analyses control for race (Asian, Black, Hispanic, Mixed, Native, White, and “other"). 
FIGURE 1. Path analysis of hypothesized model (GSS data)

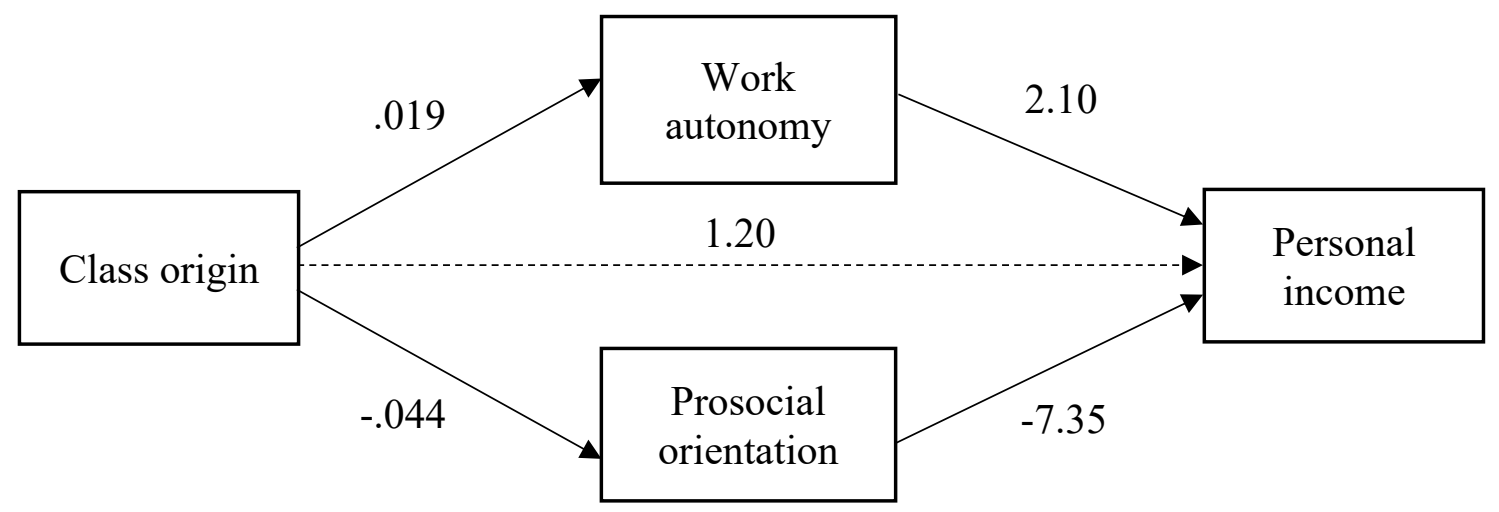

Note: All paths are significant at $p<.001$. Analyses include control variables. First-stage mediation effects reflect Models 1 and 2 from Table 3 and second-stage mediation effects reflect Model 4 from Table 5.

FIGURE 2. Path analysis of hypothesized model (NLSY97 data)

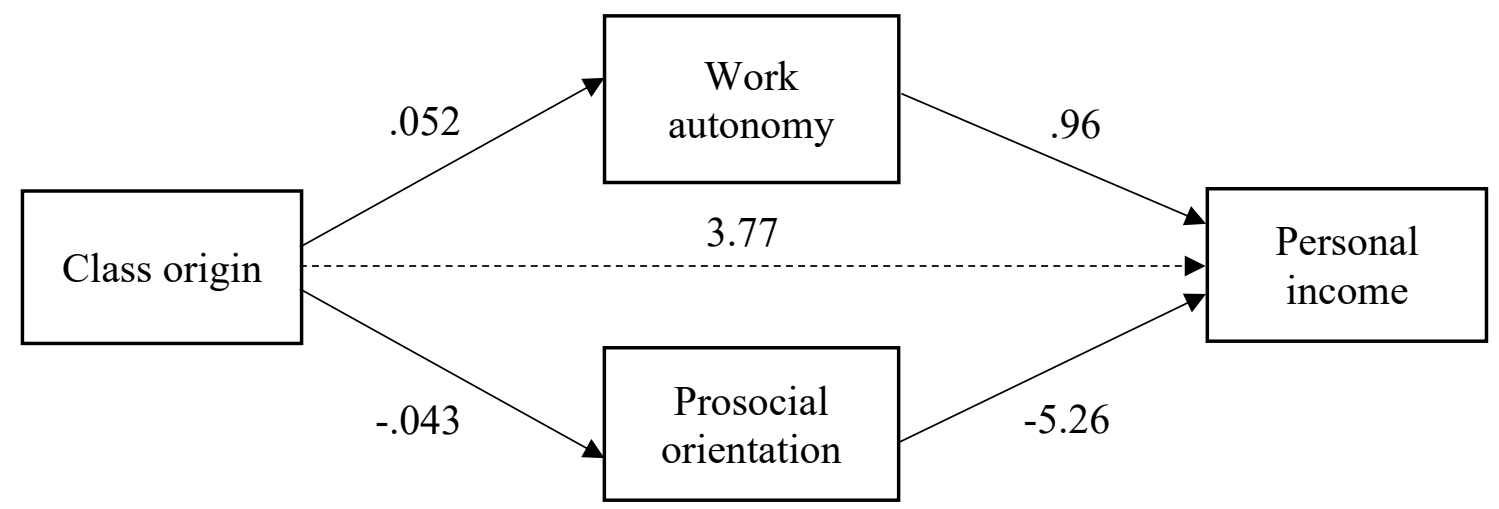

Note: All paths are significant at $p<.05$. Analyses include control variables. First-stage mediation effects reflect Model 1 from Tables 6 and 7; second-stage mediation effects reflect Model 3 from Table 8. 